\title{
Microplastics as contaminants in Indian environment: a review
}

\author{
Mansi Vaid ${ }^{1} \cdot$ Komal Mehra $^{1} \cdot$ Anshu Gupta ${ }^{1}$ \\ Received: 27 April 2021 / Accepted: 26 September 2021 / Published online: 14 October 2021 \\ (c) The Author(s), under exclusive licence to Springer-Verlag GmbH Germany, part of Springer Nature 2021
}

\begin{abstract}
The increased production and consumption scale of plastic items has led to the generation of microplastics (MPs), an emerging class of contaminants, in our environment. MPs are plastic particles less than $5 \mathrm{~mm}$ in size and could originate due to primary and secondary sources. The primary ones are generated as such in the MP size range while the secondary MPs are a result of fragmentation of larger plastic particles which eventually enters the aquatic, terrestrial and atmospheric environments. The increasing concern of MP pollution in every compartment of our environment is being globally explored, with relatively fewer studies in India. Among the total studies published on MP prevalence in the Indian environments, marine systems have received significantly higher attention compared to the other compartments like freshwater, atmosphere, terrestrial and human consumables. This review article is an effort to present current understanding of MP pollution in aquatic systems, terrestrial systems, atmosphere and human consumables of India by reviewing available scientific literature. Along with this, the review also focuses on identification of the gap areas in current knowledge and highlights way forward for future research. This would further help in meeting the goals of this emergent pollutant management.
\end{abstract}

Keywords Microplastics $\cdot$ Emerging contaminant $\cdot$ Aquatic systems $\cdot$ Atmosphere $\cdot$ Terrestrial systems $\cdot$ Human consumables

\section{Introduction}

Plastic production has seen a huge growth since the last 70 years across the globe, to such a point that we can say that we are living in a plastic world. These polymers have become indispensable in modern life because of their properties like low manufacturing cost, adaptability, water-resistant nature, high strength-to-weight ratio and high thermal and electrical insulation properties, and are prevalent in almost every area like clothing, storage, transportation, packaging and construction, and in consumer goods (GESAMP 2015). However, in view of identification of the various emerging risks to the environment and human health associated with these synthetic polymers, concern is being raised regarding the massive production and disposal of plastics (Thompson et al. 2009; Sedlak 2017). For instance, in the present

Communicated by Philippe Garrigues.

Anshu Gupta

anshurcy@yahoo.com

1 University School of Environment Management, Guru Gobind Singh Indraprastha University, Dwarka Sector 16C, New Delhi 110078, India
COVID-19 pandemic, the inadequate usage of plastic items has generated a massive chaos in the environment. In the review study by de Sousa (2021), it is elaborately discussed how a single-use plastic item like disposable face masks can impose variable levels of problems in our environment. From reports of deaths in organisms like Magellanic penguin (Spheniscus magellanicus) to generation of hazardous emissions in the environment due to incineration of infected plastic items, these synthetic materials are creating a severe threat for virtually every type of living organism thriving in our environment (de Sousa 2021). Bhuyan et al. (2021) have reviewed the global impacts of plastic exposure in different organisms and found reports of impairment in functioning of different body parts in humans, while entanglement issues, injury, accidental ingestion and fatalities in aquatic organisms.

Plastics are highly persistent in nature due to which their degradation occurs at a slower rate and their accumulation at a faster pace (Barnes et al. 2009). In the present scenario, worldwide prevalence of smaller fraction of plastics, i.e. microplastics (MPs) and nanoplastics (NPs), is gaining significant attention of the researchers globally due to their serious environmental consequences (Wright 
et al. 2013). MPs refer to any piece of plastic smaller than $5 \mathrm{~mm}$ to $1 \mu \mathrm{m}$ in size along its longest dimension and comprise polymers such as polyethylene (PE), polystyrene (PS), polypropylene (PP), polyethylene terephthalate (PET) and polyvinyl chloride (PVC) (Crawford and Quinn 2017). Depending on the specific sources of origin, MPs can be categorized into primary and secondary. Primary MPs are the ones that are intentionally manufactured by industrialists and other chemical agencies for use in cosmetics, personal care products, dermal exfoliators, etc. (Crawford and Quinn 2017), while the fragmentation of larger plastic items like fishing gear, food packaging, plastic bottles, synthetic textiles, car tyres, paints and cosmetics gives rise to a secondary fraction of MPs (Barboza and Gimenez 2015).

MPs have been present in the environment for many years; there is no doubt in this fact. They are distributed across the aquatic systems, land surface, inside biological organisms, human consumables and even in the air (Zbyszewski and Corcoran 2011; Klein et al. 2015; Prata 2018; Rezania et al. 2018; Waring et al. 2018; Barletta et al. 2019; Patel et al. 2020). The huge demand of plastic products owes to this widespread prevalence of MPs in the environment. According to the study reported by Law et al. (2020), the USA is the largest producer of plastic waste (generating around 42 million metric tons of plastic waste annually), followed by European Union, India, China, Brazil, Indonesia, Russian Federation, Germany and other countries. The gradual accumulation and subsequent fragmentation of these lead to the generation of MPs. Unfortunately, studies on this aspect is very limited yet, and out of the total 192 countries, only 22.9\% have carried out research on MPs (Ajith et al. 2020).

Plastics industry is a fast-growing industry in India, where Western India has been the largest consumer of plastics (47\%) with major consumption in the states of Gujarat, Maharashtra, Madhya Pradesh, Daman and Diu, Chhattisgarh, and Dadra and Nagar Haveli (FICCI 2014). Overall, the annual consumption of plastics in India is approximately $11 \mathrm{~kg}$ per capita (CSE 2019), and being a major consumer, it generates approximately 26 million metric tons of plastic wastes annually (Law et al. 2020), thereby holding an important position in the plastic waste generation community. Weathering and fragmentation of this plastic waste eventually leads to the generation of MPs, and its presence in various components of Indian environment is being researched by many scientists. As indicated by Ajith et al. (2020), the research on MPs has progressed in India from 2010 onwards (also represented in Fig. 1a based on our literature survey) and requires much more comprehensive studies in this domain due to various toxicities associated with this emergent pollutant.

Depending on the environmental matrix where these MPs are released, a wide array of consequences can occur. In aquatic systems, these can be ingested by the inhabiting organisms by mistaking MPs as their food, or sometimes due to their natural metabolism, organisms are exposed to MPs like in filter feeding organisms (Dowarah et al. 2020). In terrestrial systems, MPs are known to impact the functioning of organisms inhabiting these systems such as the soil dwelling invertebrates, plant pollinators and fungi (de Souza Machado
Fig. 1 Microplastic studies conducted in India. a The number of studies conducted yearwise; $\mathbf{b}$ percentage of studies conducted in different compartments; $\mathbf{c}$ percentage of studies conducted in different regions

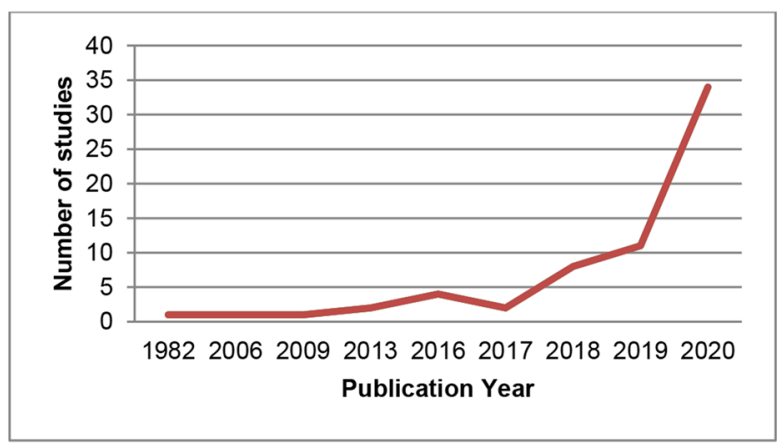

(a)

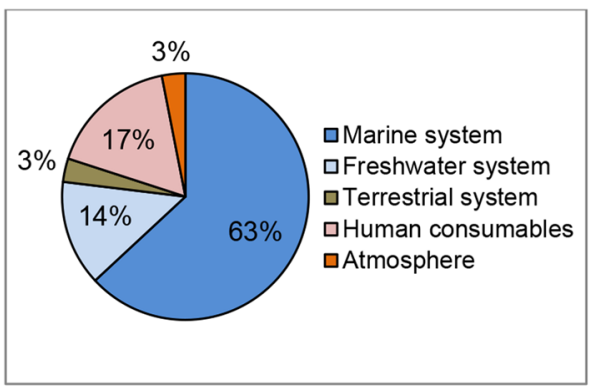

(b)

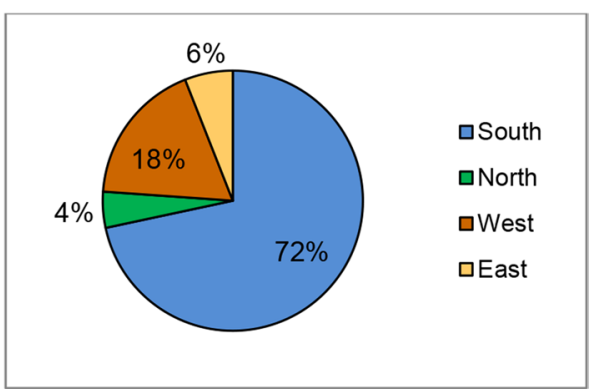

(c) 
et al. 2018; Madhav et al. 2020). While due to their increased bioavailability, subsequent changes can occur in the physical, chemical and biological properties of soil which might affect the terrestrial vegetation as well (Bi et al. 2020). In addition to this, trophic transfer of MPs or bioaccumulation can also occur (Madhav et al. 2020; Goswami et al. 2020). The wider reach of MPs has resulted in the contamination of air, water and soil, and by the processes of ingestion or inhalation, they are known to be consumed by humans as well (Mason et al. 2018; Zhang et al. 2020; Daniel et al. 2020; Selvam et al. 2020b). Ragusa et al. (2021) have found in their study that MPs have permeated the human placenta as well and possible routes of transport are indicated via respiratory and gastrointestinal systems. In addition to this, synergistic impacts of MPs are also being encountered due to the adsorption of harmful substances like persistent organic pollutants (POPs), heavy metals, pesticides, antibiotics, pathogenic microorganisms and destructive algal blooms on their surface (Naik et al. 2019; Sathish et al. 2020a). Naik et al. (2019) have further indicated ballast water as an important router for channelization of such contaminated MPs in global environmental matrices.

The pervasive occurrence of plastic pollution in different environmental matrices needs effective tracing for mitigation and control of the variable sources of this pollutant. As per the present scenario, limited reports are available to discuss the consequences of MPs prevailing in different parts of our environment. Majority of MP research has been conducted in North America, Europe and Australia while India has a very limited database in comparison to the expanse of the problems occurring due to these MP pollutants (Bhattacharya and Khare 2019). The present study is therefore an effort to highlight the immediate need of MP research in India as these pollutants create a multitude of problems in our environment.

\section{Microplastic pollution in India}

Situated in the southern portion of Asia, India is surrounded by the Arabian Sea in the south west and the Bay of Bengal in the south east and ultimately connects to the Indian Ocean. The country is situated between the latitude $8^{\circ} 4^{\prime}$ and $37^{\circ} 6^{\prime} \mathrm{N}$ and the longitude $68^{\circ} 7^{\prime}$ and $97^{\circ} 25^{\prime} \mathrm{E}$ and has a coastline of $7517 \mathrm{~km}$ (Kumar et al. 2006). For the assessment of status of MP pollution in the Indian environments, a detailed research of the literature was carried out using Google Scholar, Web of Science and SciFinder database till November 2020. A total of 64 studies conducted in different compartments of Indian environment (aquatic, atmospheric, terrestrial and human consumables) were found by searching these databases, which were further utilized to essence the construct of the present review article. A graphical representation (year-wise, compartment-wise and regionwise) of these studies is presented in Fig. 1. The locations where MP studies were carried out in India are represented in Fig. 2. Figure 1a clearly shows that the trend of MP research in Indian environments has caught the attention of the scientific community recently only. Furthermore, it is also revealed through these figures that the majority of the studies were conducted in marine environments (Fig. 1b), making a $63 \%$ contribution to the entire dataset. Figure 1c gives an overview of the percentage of studies conducted in different parts of India with maximum studies conducted in Southern India (Tamil Nadu, Kerala, Karnataka, Goa, Pondicherry, Andaman and Nicobar Islands, Lakshadweep and Indian Ocean) followed by Western India (Maharashtra and Gujarat) and Eastern India (Bihar and West Bengal) and lowest in Northern India (Delhi and Uttar Pradesh). The research interventions in freshwater systems, terrestrial systems, atmosphere and human consumables are lacking significantly at present, demanding a greater focus as these resources are equally important to us. Based on the present literature survey, three review articles concerning the presence of MPs in different environmental matrices of India were published by Veerasingam et al. (2020), Sarkar et al. (2020) and Pandey et al. (2021). The present review is an attempt to further add on to the available knowledge.

The hazards of MP pollution and its transport and accumulation in the environment (terrestrial, aquatic and atmosphere) are being researched upon globally, but the share of India in this global database is quite less. In India, this topic is slowly coming into existence. This comprehensive review is intended to summarize the research findings on MP prevalence in different compartments of Indian environment (aquatic, atmospheric, terrestrial and human consumables) along with the associated issues concerning these domains.

\section{Microplastics in aquatic environments}

\section{Marine systems}

Microplastic pollution is considered as a serious issue in the marine environment (Ma et al. 2016). These micro-sized polymers are widely distributed in world's oceans and seas, ranging from Atlantic to Pacific Ocean and from Caribbean to Mediterranean Sea (Law et al. 2010). Recently, MPs have also been discovered in Arctic sea ice, the Antarctic, remote mountain ranges and deep ocean trenches (Waller et al. 2017; Peeken et al. 2018; Jamieson et al. 2019; Allen et al. 2019). The distribution of MPs is quite versatile in the global marine systems, and their presence has been seen prominently in the benthic, pelagic and shoreline sections of these environments (Wagner et al. 2014; Barletta et al. 2019). Approximately $80 \%$ of the marine plastic debris 
Fig. 2 MP studies conducted in different parts of India (highlighted with a red star). The geographic map was developed using ArcGIS Desktop Advanced 10.8.1

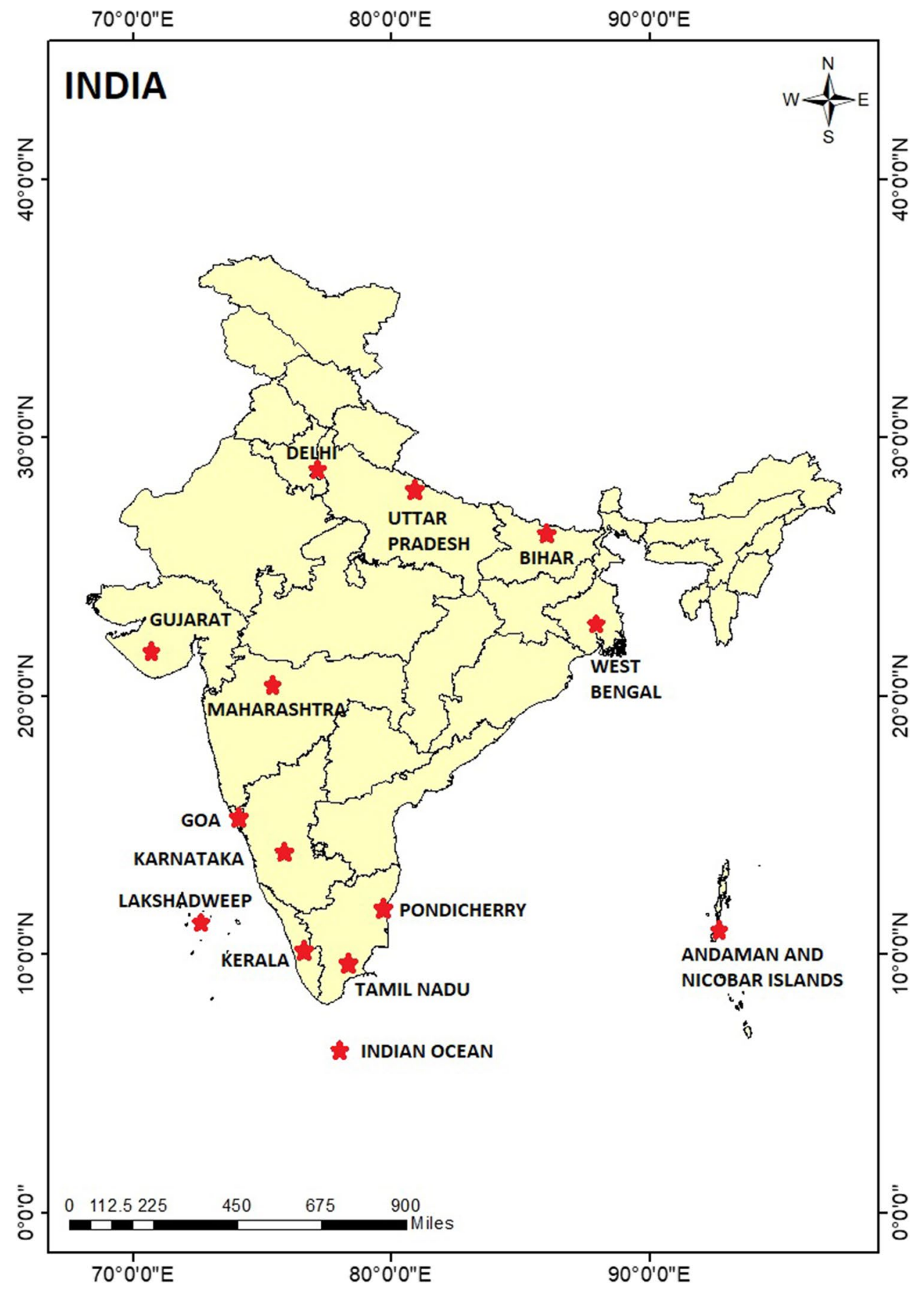

originate from inland sources and are majorly transported to the oceans through rivers (Mani et al. 2016). The contamination of marine environments with MPs is dependent on several factors of natural and anthropogenic origin. Natural ones include wind currents, coastline geology, etc., while anthropogenic ones comprise mismanaged plastic debris releases, unregulated industrial discharges, etc. (Barnes et al. 2009). These MPs are capable of escaping even the water treatment plant processes (Fok et al. 2017). Furthermore, MPs can be transported via inland streams to estuaries and the marine environment (Lechner et al. 2014; Rech et al. 2020). In a study by Selvam et al. (2020a), Punnakayal estuary situated in the south-east coast of India was found to be contaminated with up to 19.9 MPs per L, indicating the capability of this estuary for MP channelization from inland sources to the Gulf of Mannar. In another study by Manickavasagam et al. (2020), the transport of plastic debris from densely populated areas to seas via South Juhu creek was estimated. The study revealed that a major proportion of transported plastic debris comprised macroplastic and megaplastics, 
which undergoes fragmentation during their course and ultimately converts into MPs, which is an important issue to be addressed. With this ongoing scenario of plastic debris mismanagement, it has been predicted that by the year 2050, there will be a greater number of MPs in our oceans than the total number of fishes (World Economic Forum 2016).

The global contribution of different geographical areas with respect to marine MP debris (majorly primary MPs) was analysed by Ajith et al. (2020), revealing a $15.9 \%$ contribution by Southeast Asia, $17.2 \%$ by North America and $8.7 \%$ by Africa and Middle East. Numerous expeditions have been carried out by researchers for estimating the abundance of MPs in the Pacific Ocean, Atlantic Ocean, Bay of Bengal, Southern Ocean and other marine regions; however, the Indian Ocean has been relatively less focussed and less explored (Ajith et al. 2020). Investigations of marine MPs are gradually pacing up in India, and as per the present survey, the number of studies is higher for sediments in comparison to the water and biota counterpart. Table 1 shows the summary of MP studies conducted in the marine system of India comprising sediments and surface water. In addition to the abundance of MPs found in each of these matrices, studies reporting the presence of some other contaminants (conducted by the same author or different authors) at the same sites have also been mentioned. This has been done because MPs have a great potential to adsorb a variety of contaminants due to their large surface area-to-volume ratio; hence, incorporation of these studies will aid in understanding the plausible risks associated with these MPs and pollutants in the same compartment (Browne et al. 2013; Brennecke et al. 2016). The next three sub-sections critically analyse the literature published for MP pollution in marine environments of India, and it has been broadly categorized into MP occurrence in marine sediments, marine waters and marine organisms.

\section{Marine sediments}

The accumulation of MPs in the benthic layers, particularly the sediments, starts occurring when their density exceeds that of seawater $\left(>1020 \mathrm{~kg} / \mathrm{m}^{3}\right)$; otherwise, they float on the surface (Cauwenberghe et al. 2015). Sediments are known to act as the long-term sinks of MPs because floating particles are easier to remove as compared to those present in the sediments (Lima et al. 2014). MPs have been widely reported in the marine sediments of Gujarat, Tamil Nadu, Goa, Pondicherry, Maharashtra, Kerala, Karnataka, Andaman and Nicobar Islands and Lakshadweep. The preliminary study on MP contamination in marine environments of India was initiated by Reddy et al. (2006), in which they analysed the intertidal sediments at a ship-breaking yard in Gujarat. The characterization of MPs using Fourier Transform Infrared (FTIR) spectroscopy revealed that nylon, polyester, polyurethane and polystyrene were the major polymers in the sediments, which are generally used in the construction of ships.

Beaches are an important reservoir of highly fragmented plastic debris and can transport these MPs to coastal waters (Fok et al. 2017). MPs in these beaches arise due to different natural and anthropogenic sources. Anthropogenic sources include fishing, tourism, recreational, religious, port and industrial activities, mismanaged plastic waste and untreated wastewater discharges while natural sources include surface and wind currents, aeolian processes, run-off and riverine transport (Jayasiri et al. 2013b; Balasubramaniam and Phillott 2016; Veerasingam et al. 2016b; Karthik et al. 2018; Vidyasakar et al. 2018, 2020; Tiwari et al. 2019; Maharana et al. 2020; Robin et al. 2020). A significant majority of MPs found in these studies are irregularly shaped fragments. These studies further suggest that the intensity of natural and anthropogenic activities determines the MP abundance in a particular area. For instance, MPs studied across the six beaches in Puducherry showed a significant correlation with the rate of tourism activities (Dowarah and Devipriya 2019). Likewise, in another study by Karthik et al. (2018), 25 beaches of the south coast (Tamil Nadu) were analysed and it was found that beaches adjacent to the rivers had higher MP abundance, suggesting majority of these particles were transported by rivers from land-based sources.

Due to the easy accessibility and sampling, sandy beaches have been the main focus of researchers for identifying the abundance of MPs in marine environments of India. Based on the literature review for MP sampling in Indian beaches, it is observed that variable sampling procedures were used by different researchers. Sampling was done using forceps, non-plastic spoon, spatula, tweezers or shovel from quadrants of various sizes like $25 \times 25 \mathrm{~cm}^{2}, 30 \times 30 \mathrm{~cm}^{2}, 50 \times 50$ $\mathrm{cm}^{2}, 1 \times 1 \mathrm{~m}^{2}$ and $2 \times 2 \mathrm{~m}^{2}$ (Jayasiri et al. 2013a; Veerasingam et al. 2016a, b; Dowarah and Devipriya 2019; Sathish et al. 2019, 2020c; Ashwini and Varghese 2019; Jeyasanta et al. 2020b; Sundar et al. 2020; Maharana et al. 2020; Robin et al. 2020). Collection of deep sea sediment samples was preferably done using a vessel and specialized equipment including the Van Veen grab sampler, the Peterson grab sampler and a box corer (Sruthy and Ramasamy 2017; Goswami et al. 2020; Jeyasanta et al. 2020a; James et al. 2020; Patterson et al. 2020). After sediment collection using the grab sampler, sieving was also done for some sites to separate samples in different size ranges like $0.5 \mathrm{~mm}, 3 \mathrm{~mm}, 1 \mathrm{~mm}$ and $5 \mathrm{~mm}$ (James et al. 2020; Patchaiyappan et al. 2020a). For extraction of MPs, wet peroxide oxidation and density separation were the most preferably used methods. In some studies, prior to density separation, treatment with acids like hydrochloric acid was also given in order to remove the carbonates (Vidyasakar et al. 2020). For density separation, sodium chloride $(\mathrm{NaCl})$ was found to be the most commonly 


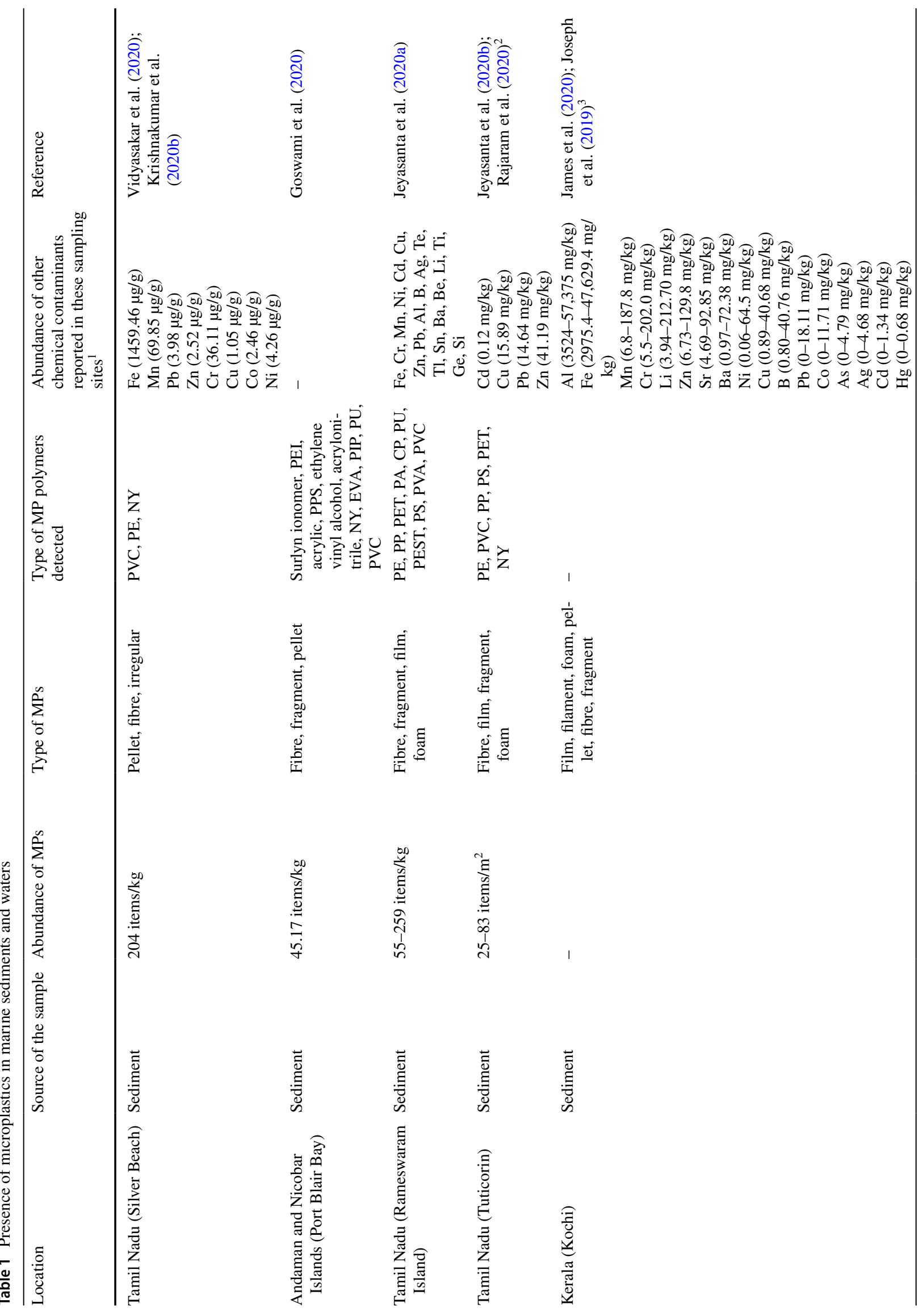




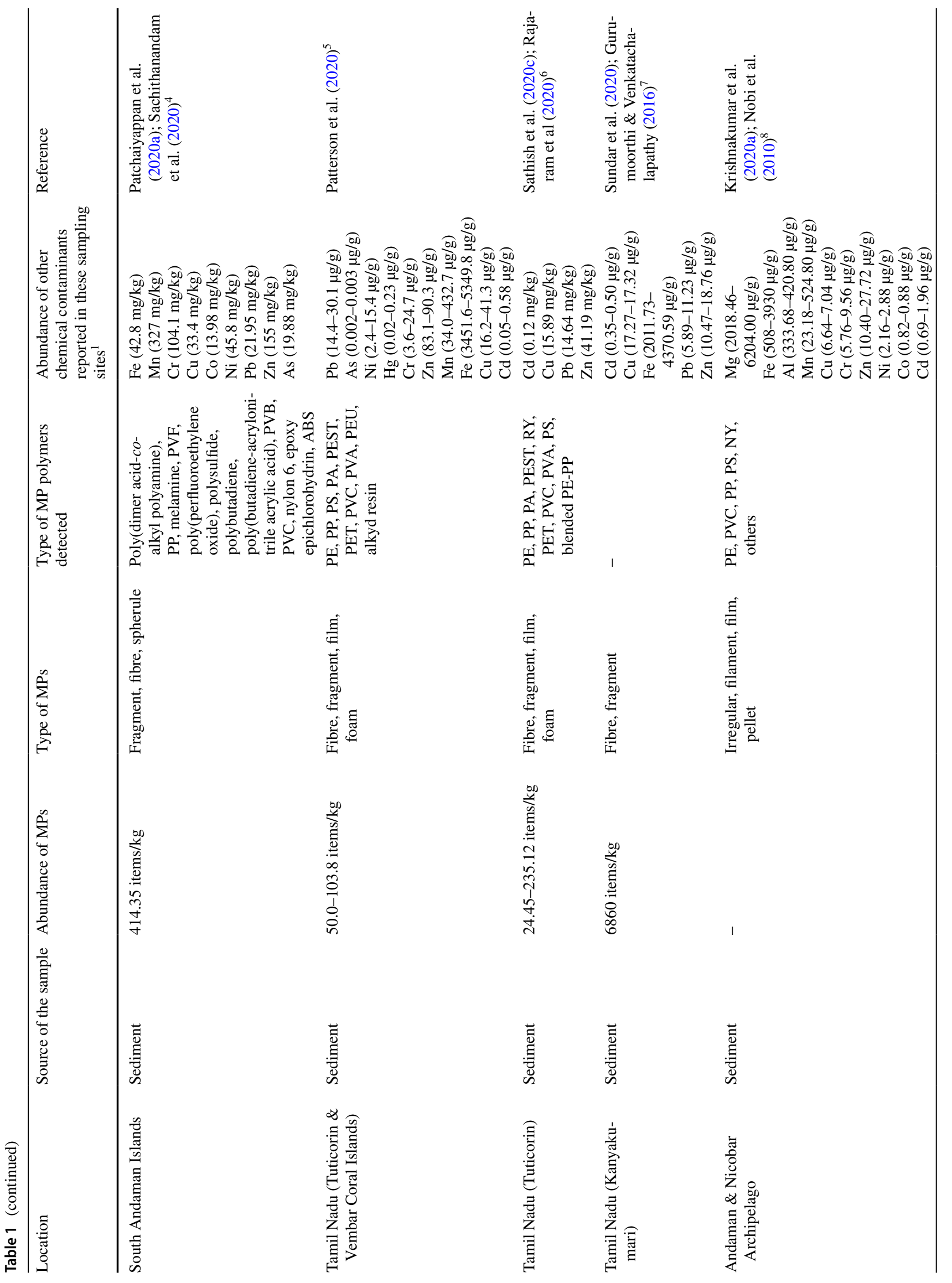




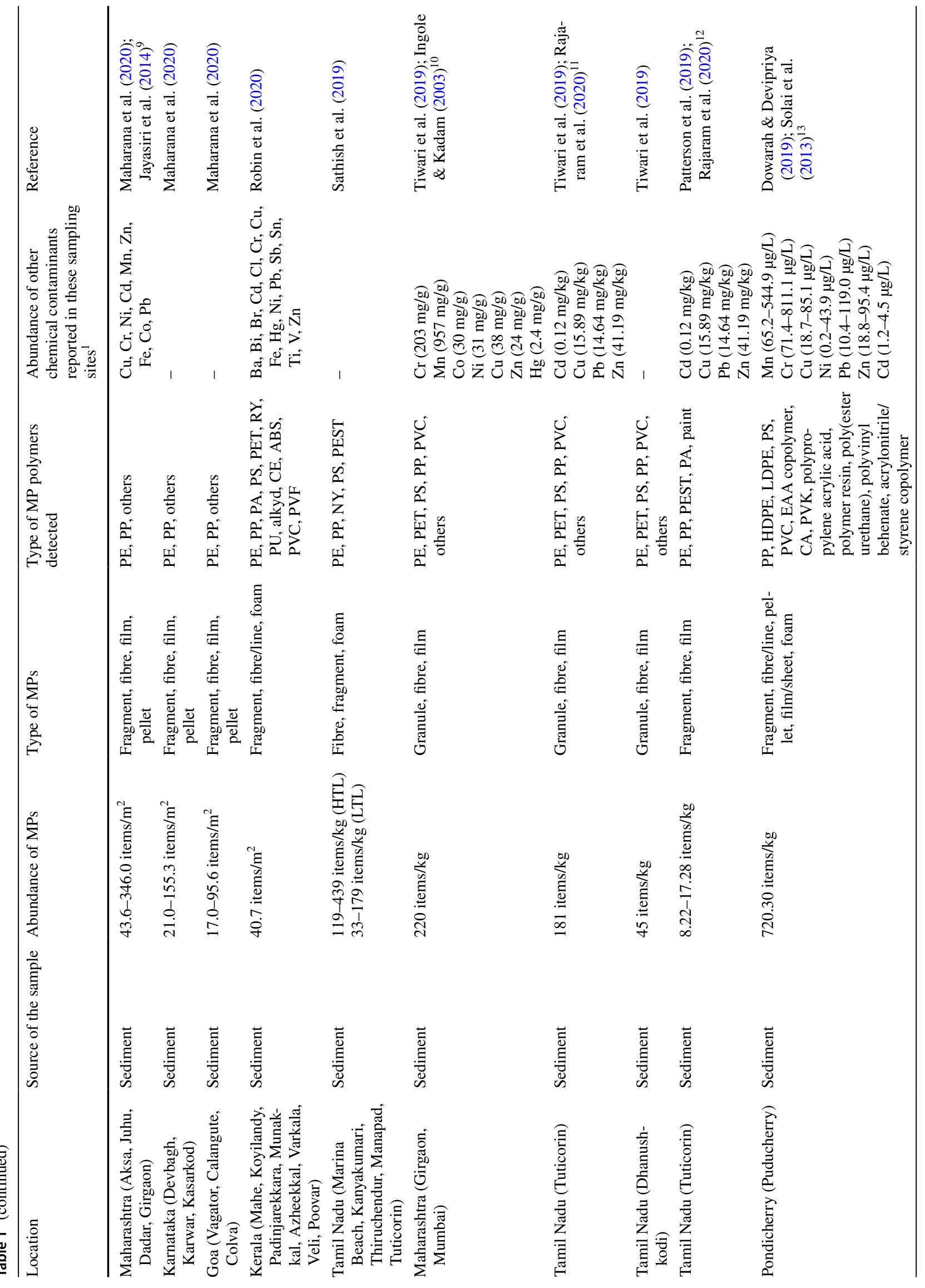




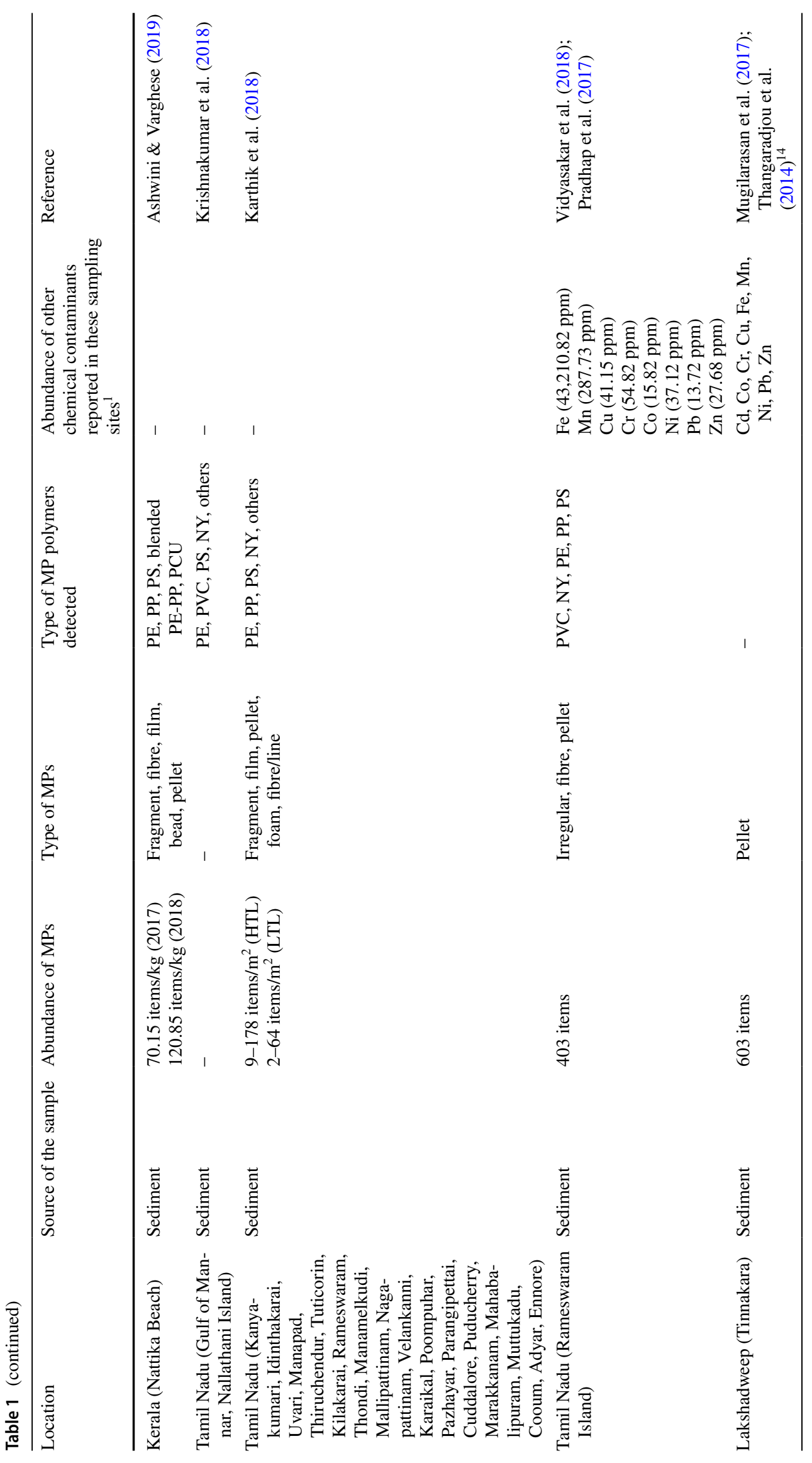




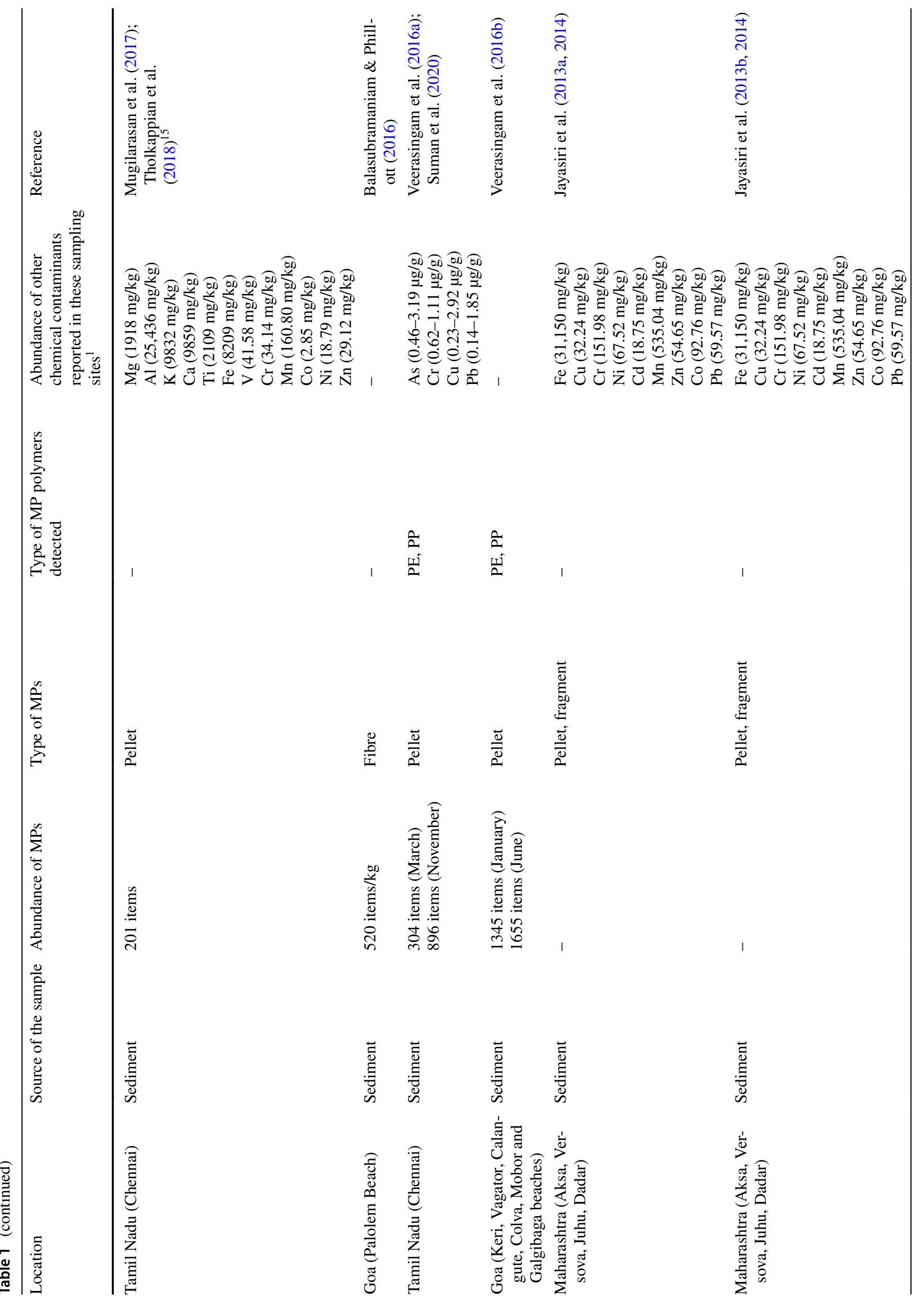




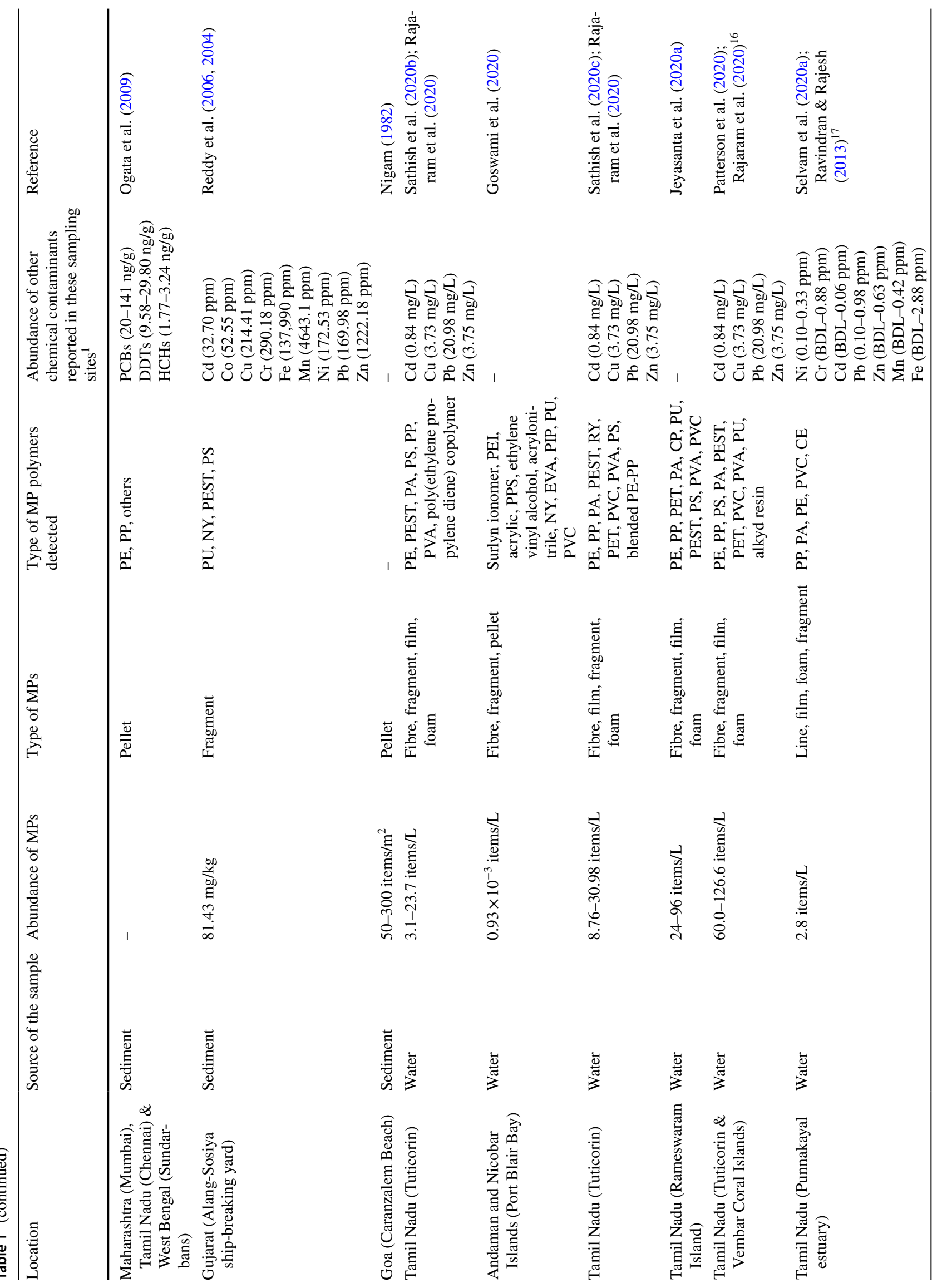




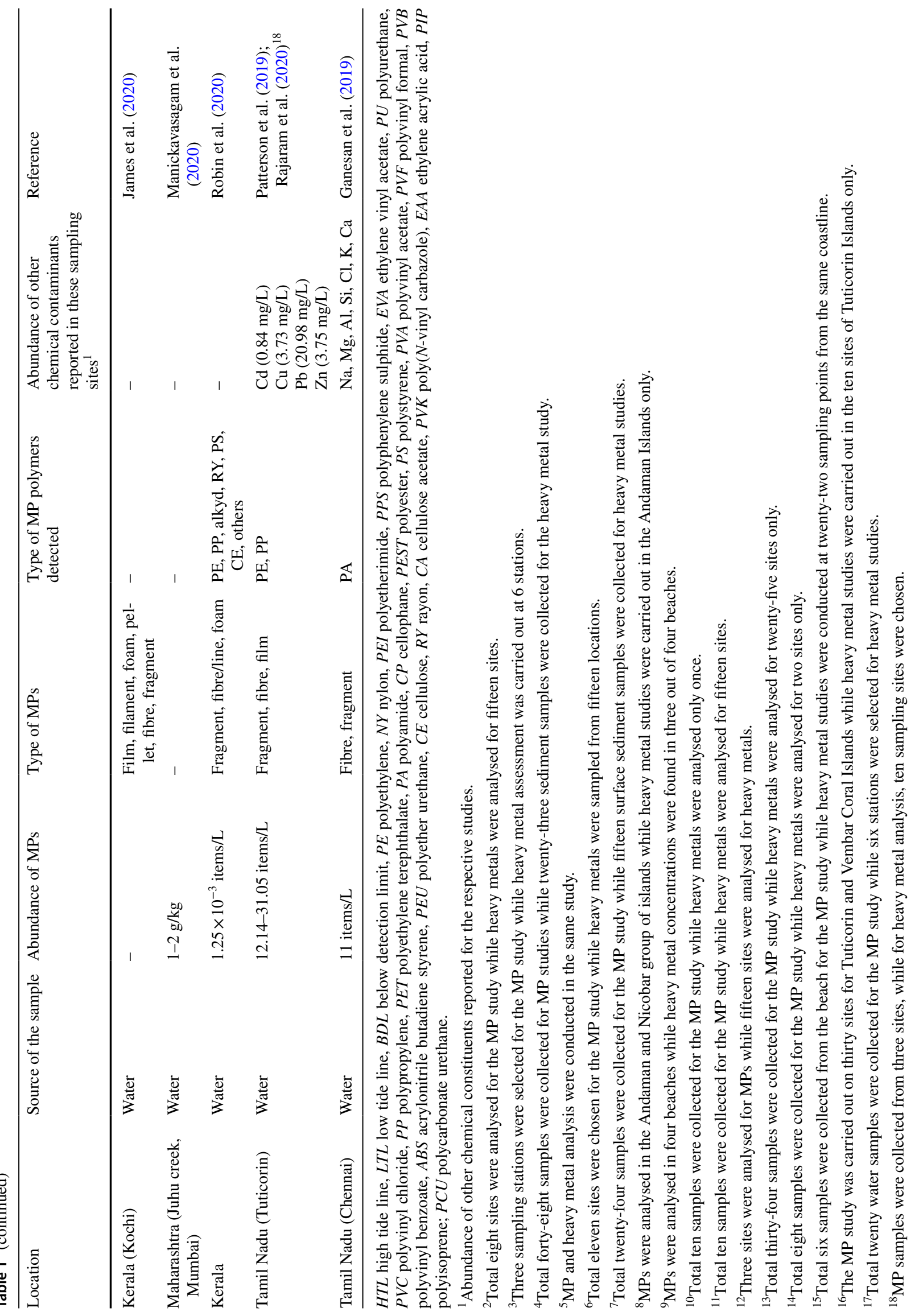


used salt whereas zinc bromide $\left(\mathrm{ZnBr}_{2}\right)$, zinc chloride $\left(\mathrm{ZnCl}_{2}\right)$, sodium iodide $(\mathrm{NaI})$, calcium chloride $\left(\mathrm{CaCl}_{2}\right)$ and sodium bromide $(\mathrm{NaBr})$ were preferred for the separation of heavier polymers (Tiwari et al. 2019; Sathish et al. 2019; Patterson et al. 2019, 2020). After treatment, supernatant solution was subjected to filtration and sorting and isolation of MPs was carried out under a microscope. Identification of MPs was preferably done using Attenuated Total Reflectance Fourier Transform Infrared (ATR-FTIR) spectroscopy while other techniques like fluorescence microscopy using Nile red dye (Patchaiyappan et al. 2020a) and Raman spectroscopy (Dowarah and Devipriya 2019) were also used. Present variations in the sampling and analytical procedures for MPs could lead to a significant bias in the overall output as indicated by Müller et al. (2020). In this study, it was found that MP analysis using different procedures can lead to large variances in the overall results for the same dataset. This biasness would cause difficulties in comparison of MP abundance and distribution data in global environmental matrices, as the present scenario of MP research in Indian environments is already restricted to certain regions; hence, adoption of such variable analytical protocols would lead to limitations in the data comparability and applicability. This issue demands that the concerned stakeholders take necessary steps to standardize the MP sampling and analytical procedures at the national as well as global level, so that the creation of MP database for these environmental matrices is harmonized.

\section{Marine waters}

Low-density MPs are reported to be the predominant versions of plastic particles in the surface layers of the marine waters (Derraik 2002), and the attachment of fouling organisms to these MPs may lead to their sinking in the benthic layers (Browne et al. 2010). In contrast, high-density MPs including PVC, PEST and PA are found in the benthic layers (Barnes et al. 2009); however, due to the variations in hydrodynamic conditions (flow rate, tidal fronts, etc.), these particles can sometimes remain in the suspension as well (Browne et al. 2010).

MP samples in Indian marine waters were collected using different techniques comprising manual collection in glass bottles (Sathish et al. 2020c; Ganesan et al. 2019) or using a boat equipped with various types of nets such as manta trawl net, neuston net and plankton net of different mesh sizes (Patterson et al. 2019, 2020; Goswami et al. 2020; Sathish et al. 2020b; Jeyasanta et al. 2020a; James et al. 2020; Robin et al. 2020) or using a Teflon pump and subsequent filtration through stainless steel sieves (Selvam et al. 2020a). After collection, samples were either refrigerated or additional preservation was done by adding 4-5\% formalin (James et al. 2020; Selvam et al. 2020a) or 5\% formaldehyde solution (Sathish et al. 2020b; Patterson et al. 2019). Further processing of the collected samples for the separation of MPs was carried out using wet peroxide oxidation followed by density separation or density separation alone. As mentioned in the previous section, the variations adopted in MP sampling and analytical procedures in the present dataset can also lead to inconsistencies. Thus, it is important to prioritize standardized MP sampling and analysis protocols in order to avoid any discrepancies and have more significant and uniform database for marine waters also.

The choice of selected locations by the researchers and limited explorations of Indian marine environments are insufficient to identify the role of this country in global marine MP pollution. Due to the ease of sampling, beaches have been the main focus of researchers whereas water column has gained comparatively lesser attention. A portion of southern coastline has been extensively studied while the rest of the regions have remained untouched. Hence, the current scenario depicts that the research explorations in India are non-uniform and require a much greater number of studies to fill in the gap areas for better understanding of the MP pollution in marine domain in India.

\section{Marine organisms}

A huge amount of population in India is dependent on the coastal and marine ecosystems and their resources (Kumar et al. 2018). Despite this fact, the marine ecosystem is under constant threat due to various anthropogenic activities. Among the different threats that marine organisms are facing, MPs are emerging as a new and relatively less studied threat. The present understanding of MP prevalence in the marine biota suggests that a significant proportion of organisms are at risk of ingesting these synthetic polymers which can lead to variable levels of health complications. Studies have found that due to the increasing exposure to MPs, marine biota can experience oxidative stress, reduction in filtration capacity, inflammation in tissues, impaired digestive tract, pseudo-satiation and reduced immunity (Dowarah et al. 2020; Maharana et al. 2020; Daniel et al. 2020; Sathish et al. 2020b). In India, studies on ingestion of MPs by fishes have been a major attraction for the researchers. In fishes, MPs have been found in the range 0.05 to 10.65 items per individual while the range of MPs found in marine waters is 0.93 to $126.6 \times 10^{3}$ items $/ \mathrm{m}^{3}$. In recent investigations on impact of MPs in a marine fish (Carassius carassius), it was found that ingestion of MPs in the range of 15 to 76 items per individual for the exposure duration of 6 weeks could lead to a decrease in weight, disruptions in the buccal cavity, inflammations and microgranulomas in the liver (Jabeen et al. 2018; Wang et al. 2020a), while based on abundance in their habitat, a concentration of 100 items/L for the exposure 


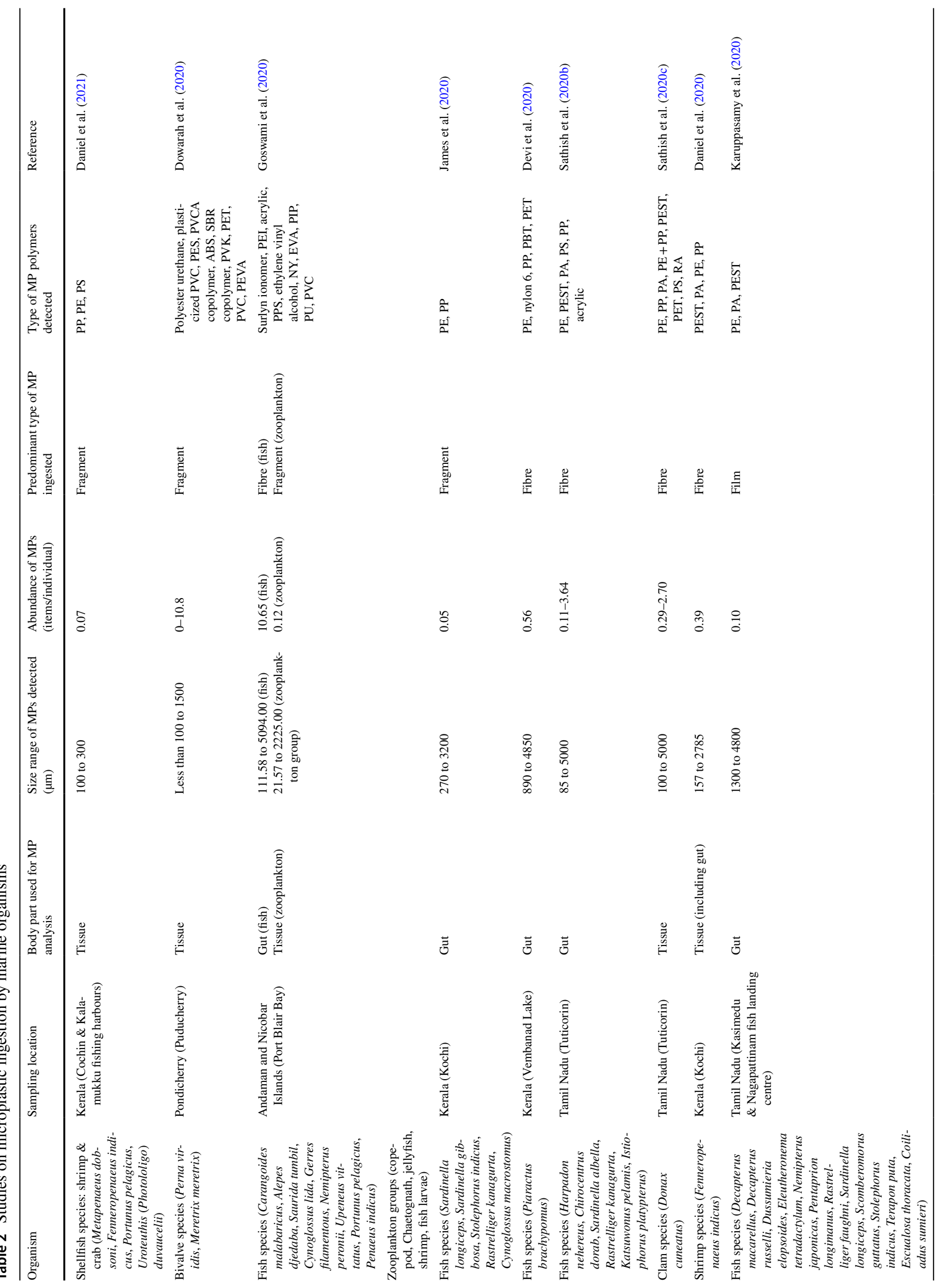


duration of $96 \mathrm{~h}$ could lead to reductions in predatory performance and overall efficiency in Pomatoschistus microps (Carlos de Sá et al. 2015; Wang et al. 2020a). Also, from the literature, it can be concluded that these types of studies were more prevalent in the states of Tamil Nadu and Kerala in India. Table 2 shows the summary of MP occurrence in Indian marine biota.

According to the current research studies, the sampling protocols for assessment of MPs in marine organisms generally involve either direct capture using fishing nets or purchase of samples from the market and immediate storage in ice boxes until further analysis in the laboratory. Analysis was primarily carried out by dissecting the organism followed by direct visual observations under a microscope, or the dissected contents were further digested using aqueous or alcoholic potassium hydroxide $(\mathrm{KOH})$, nitric acid $\left(\mathrm{HNO}_{3}\right)$ or hydrogen peroxide $\left(\mathrm{H}_{2} \mathrm{O}_{2}\right)$. MPs were then finally isolated from these samples and subjected to microscopic observations and characterization for confirmation of the plastic nature and polymer. In India, majority of studies have been conducted to find the prevalence of MPs in marine organisms. We could find only one study in the literature by Goswami et al. (2020) who have done extended research on trophic transfer and bioaccumulation of MPs. Since MPs pose a serious threat to animals and human health due to ingestion of these compounds by marine biota followed by bioaccumulation and biomagnification through food chain, more extensive research is required in this domain for better understanding of the risks associated with MP ingestion by marine biota.

\section{Freshwater systems}

Microplastic pollution has been identified as a pervasive and damaging environmental stressor in the world's ocean, but still only a small body of research has been conducted on freshwater MPs, despite the fact that freshwater is a source for drinking water. Though research in this domain is gradually progressing all over the world, unfortunately, this domain has not gained enough attention in India according to the literature reviewed (Sruthy and Ramasamy 2017; Sarkar et al. 2019; Ganesan et al. 2019; Gopinath et al. 2020; Manikanda Bharath et al. 2020; NPC 2020; Amrutha and Warrier 2020; Ram and Kumar 2020; Selvam et al. 2020a). This calls for the urge to assess the MP contamination in freshwater systems of India. A detailed study on freshwater ecosystems will help the researchers to gain an insight on the sources, fate and associated toxicity of these MPs in these environments.

MP studies in Indian freshwater systems have focussed primarily on the surface water and sediment sections of lakes and rivers. Groundwater samples have also been analysed but with a relatively less fraction of studies in comparison to the lakes and rivers. These studies are summarized in Table 3. In addition to MP abundance, other contaminants/ pollutants reported by the same author or different authors at these respective sampling sites have also been mentioned as discussed earlier for marine systems. Based on the MP prevalence trends in Indian freshwater systems, the following three sub-sections discuss the scenario of MP pollution in Indian lakes, rivers and groundwater.

\section{Lakes}

Lakes are the major resources of freshwater as they hold about $90 \%$ of the world's fresh surface water (Bengtsson and Herschy 2012), but due to increased human interventions, these resources are facing a direct load of heavy metals, eutrophication and many other types of pollution. MPs, an emergent contaminant, are appearing as a relatively new type of pollution in these water bodies. The presence of MPs in Indian lakes was recently explored, and a major source of these synthetic polymers was identified as the fragmentation of macroplastic debris (Sruthy and Ramasamy 2017; Ganesan et al. 2019; Gopinath et al. 2020; Manikanda Bharath et al. 2020). Other responsible factors could be leakage of primary MPs from personal care products or industries, riverine transport of MPs, run-off activities due to rainfall and dry deposition. MP investigations in Indian lakes were conducted in sediments and surface water sections. For surface waters, sample collection was generally conducted using glass bottles (grab sampling), nylon plankton nets $(20 \mu \mathrm{m}$ mesh size) or plankton nets ( $120 \mu \mathrm{m}$ mesh size) (Ganesan et al. 2019; Gopinath et al. 2020; Manikanda Bharath et al. 2020), while for sediment samples, the Van Veen grab was preferred (Sruthy and Ramasamy 2017; Gopinath et al. 2020; Manikanda Bharath et al. 2020). For MP extraction, standard protocols of National Oceanic and Atmospheric Administration (NOAA) were generally preferred; however, Ganesan et al. (2019) analysed the samples by direct filtration without any pre-treatment followed by visual observations under the microscope for MP identification.

\section{Rivers}

Approximately $80 \%$ of the total plastic debris in the marine environments are coming from terrestrial sources which are known to be transported by rivers (Wagner et al. 2014). In a recent study by Napper et al. (2021), approximately 1-3 billion of MPs are estimated to be daily discharged into the Bay of Bengal by the Ganges, Brahmaputra and Meghna rivers. However, MPs found in the rivers do not reach oceans as a whole but some pieces get accumulated in their sediments, which can act as an important sink of MPs (Sruthy and Ramasamy 2017; He et al. 2020). River water pollution is a global problem, 


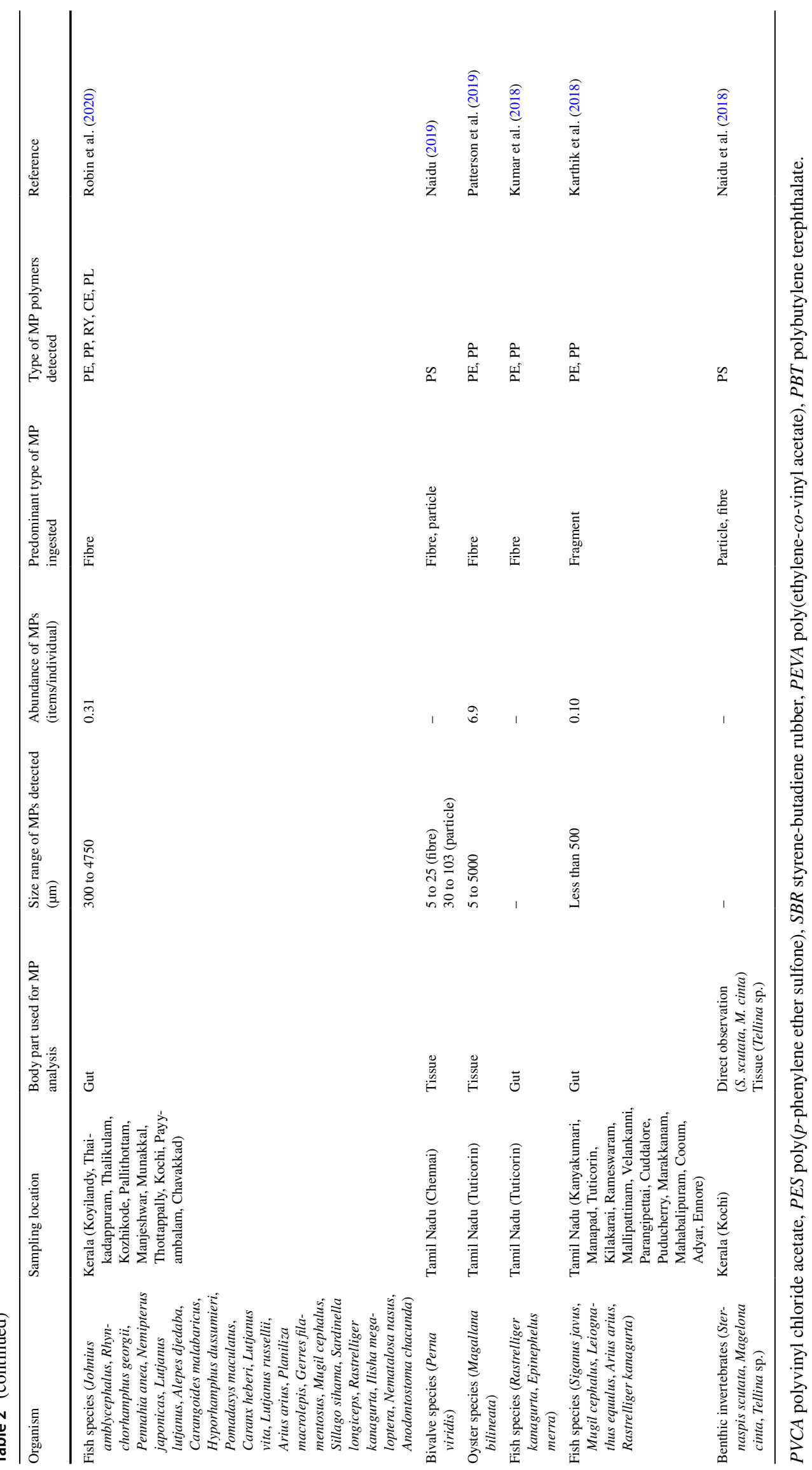


and being home to around 20 river basins (Central Water Commission 2019), a majority of basins in India are victim to different types of pollution like heavy metals, pesticides, POPs and other harmful biological and chemical compounds. Inefficient waste management practices are further leading to the discharge of plastic wastes in these rivers particularly MPs. Sources of MPs in Indian rivers primarily comprise fragmentation of macroplastic debris items like plastic packaging materials, ropes, fishing nets, wrappers, pipes and synthetic textiles. Furthermore, variations in the hydrodynamic and climatic factors like wave height, flow velocity and wind speed facilitate channelization of these synthetic polymers to different sections of the water column (Sarkar et al. 2019; NPC 2020; Amrutha and Warrier 2020; Ram and Kumar 2020). Studies conducted on contamination of Indian rivers with MPs have analysed the surface water and sediment layers. Sample collection from surface waters was preferred using stainless steel bucket and sieves or neuston nets $(300 \mu \mathrm{m}$ mesh size), while for sediments, stainless steel spoon or scoop was preferred. Extraction of MPs from the collected samples was then done using wet peroxide oxidation method or density separation or both. Depending on the load of organic matter in the collected sample, preference to wet peroxide oxidation is given because its primary aim is to digest the labile organic matter for easy separation and identification of MPs (Amrutha and Warrier 2020).

\section{Groundwater}

Globally, water resources are facing a high risk of contamination with MP pollutants. However, for occurrence of MPs in groundwater of India, only two studies could be found in the present literature survey (Ganesan et al. 2019; Selvam et al. 2020a). Tourism-dominated activities, industrial and domestic effluent discharges, fragmentation of mismanaged plastic debris and riverine leaching are some of the major reasons of MP contamination in the groundwater across India as per the present analysis. Groundwater samples tested for MP contamination followed different methodologies of collection and processing. In the study conducted by Ganesan et al. (2019), samples were directly collected in the glass bottles and MP isolation was performed by filtration of the samples in the laboratory. Observation of MPs collected on the filter was then done using an optical microscope. While in another study by Selvam et al. (2020a), sample collection was preferred using a Teflon pump followed by on-site filtration through stainless steel sieves (50 $\mu \mathrm{m}$ mesh size). Further processing and extraction of MPs was conducted using wet peroxide oxidation method and subsequent filtration of this oxidized solution. Filters were then analysed under a stereomicroscope for MP presence and identification. In the same study, adsorption capacities of PP, PVC, PA, CE and $\mathrm{PE}$ were tested against the heavy metals $\mathrm{Mn}, \mathrm{As}, \mathrm{Cd}$, $\mathrm{Zn}, \mathrm{Cr}, \mathrm{Cu}$ and $\mathrm{Pb}$. It was found that MPs comprising of $\mathrm{PP}$ and PE polymers could adsorb significant quantities of metals even in trace concentrations, depicting a situation of severe risk if these MPs are ingested by any of the aquatic or terrestrial biota (Selvam et al. 2020a).

\section{Microplastics in atmosphere}

Air is one of the most important requirements of living beings to survive and exist. Out of the many pollutants present in the atmosphere, airborne MPs have recently emerged as contaminants of concern. MPs in the air are able to enter directly in the human body and pose significant risk to human health (Gasperi et al. 2018; Prata 2018). Early studies concerning airborne MPs were reported by Dris et al. (2016) in Paris and it was found that MP fibres can become airborne, after their disintegration from its source. The major source of MPs in air remains synthetic textiles (Dris et al. 2016) while gradual releases from landfills, streets and incomplete incineration of garbage is also important to be considered (Liu et al. 2019). Several experiments were conducted to check airborne MP-associated risks to human health. For instance, Vianello et al. (2019) used a breathing thermal manikin (BTM) to study the effect of indoor air exposure (24-h duration) on humans and found that an average human can inhale up to $272 \mathrm{MP}$ particles from indoor air within $24 \mathrm{~h}$. Inhalation of airborne fibres is much more prevalent in comparison to other shapes (Wang et al. 2020b; Narmadha et al. 2020). Prata (2018) in her study has made a very good review on health implications to humans due to airborne MPs. The author has reported that the workers associated with textile industries (which are a major source of fibrous MPs) are known to suffer from various ailments including dyspnea, interstitial inflammations in their airway and respiratory failure in extreme cases due to this exposure (Prata 2018).

India being one of the most polluted cities with respect to air pollution is also at high risk of airborne MP contamination. In a recent report by IQAir (2020), 22 of the 30 most polluted cities in the world were present in India, particularly in terms of $\mathrm{PM}_{2.5}$ (particulate matter less than $25 \mu \mathrm{m}$ in size). MPs in conjunction with other pollutants present in the Indian atmosphere can lead to various health complications, but due to the significant lack of research in this domain, the severity of situation is unclear. During the present literature survey, two studies reporting the presence of MPs in Indian atmosphere (Narmadha et al. 2020; Wang et al. 2020b) were located 


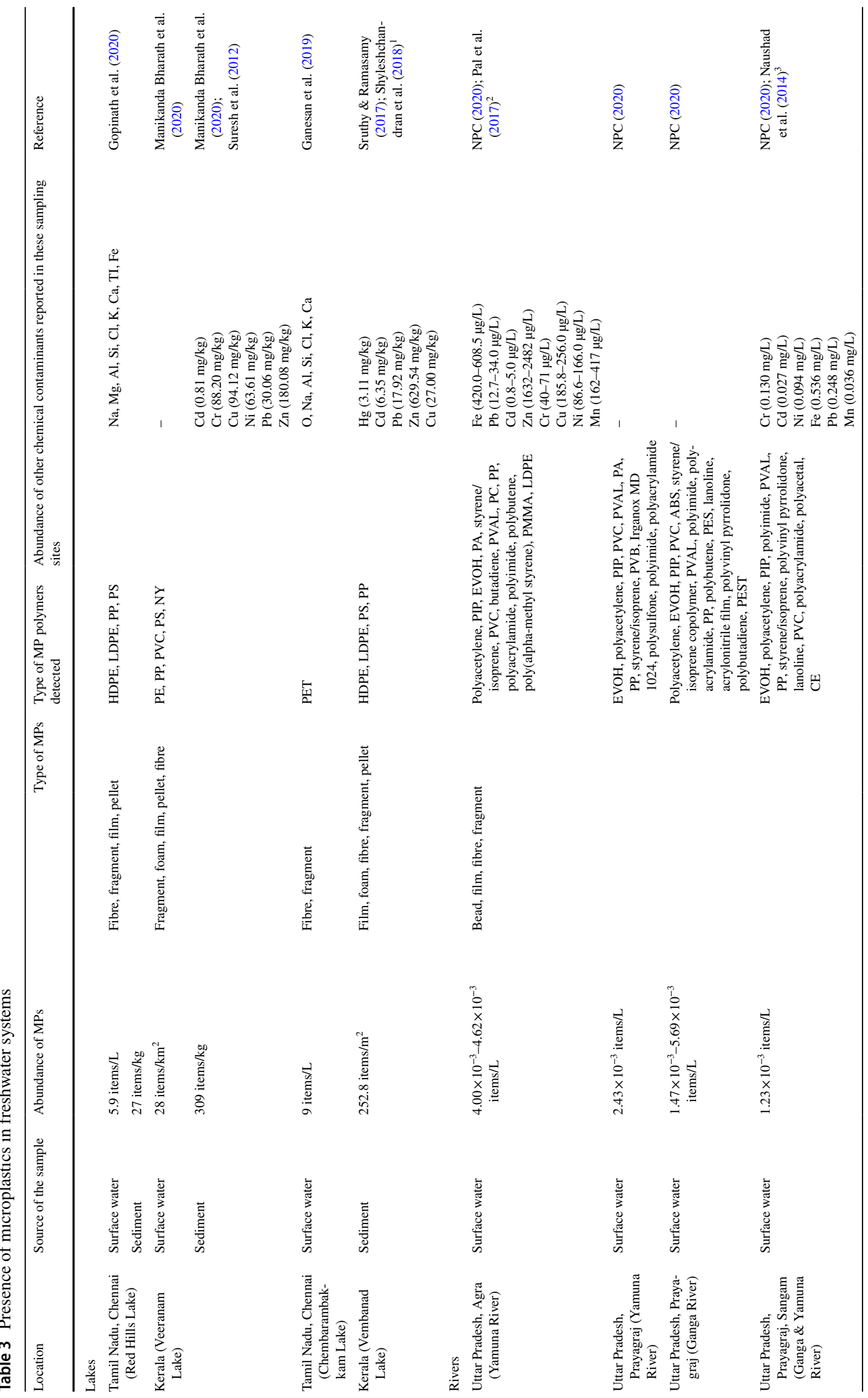




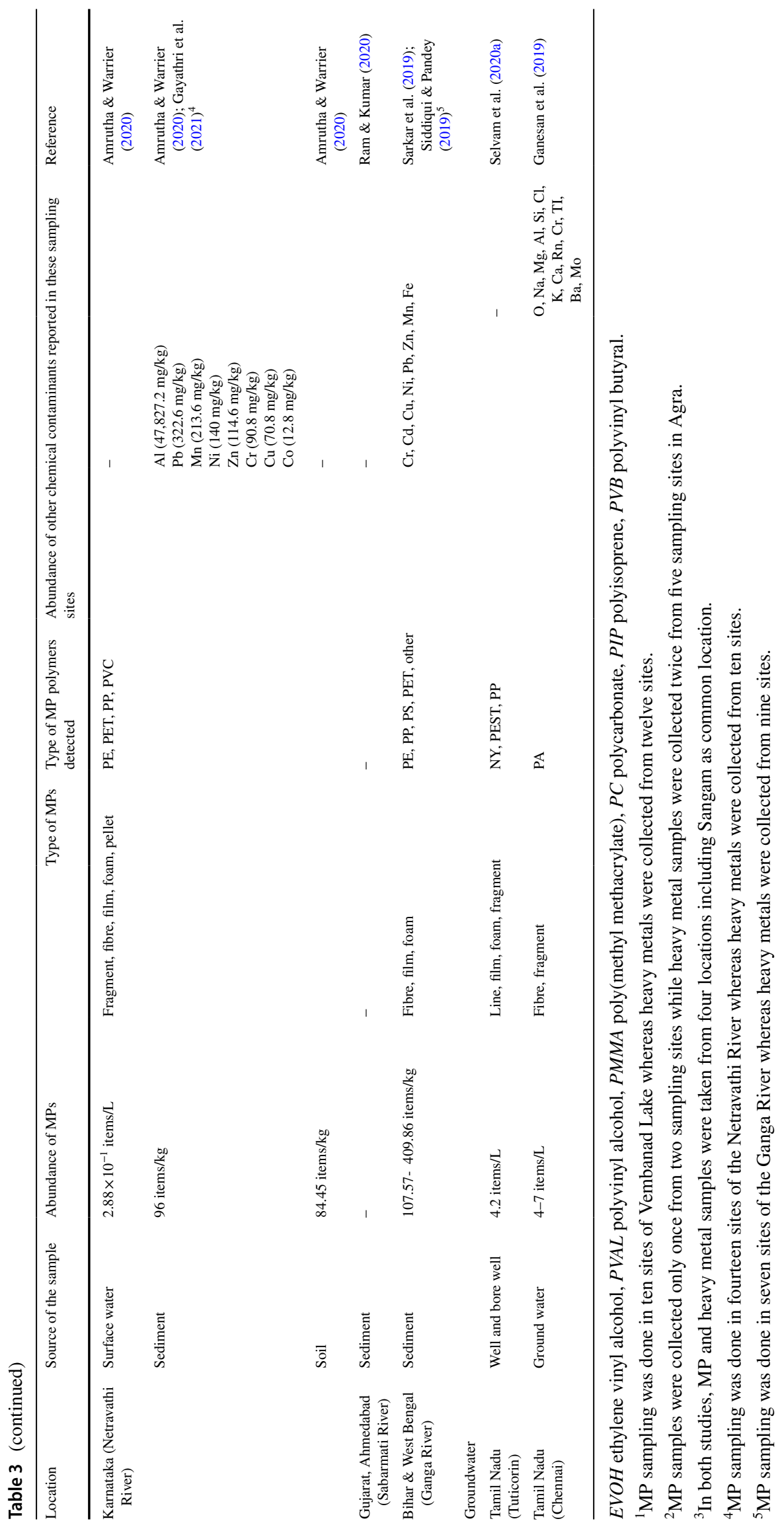


Table 4 Presence of microplastics in atmosphere

\begin{tabular}{|c|c|c|c|c|}
\hline Location & Sampling technique & Concentration of MPs & Type of MPs & Reference \\
\hline Maharashtra (Nagpur) & $\begin{array}{l}\text { Collection by high-volume samplers using polytetra- } \\
\text { fluoroethylene (PTFE) filter paper }\end{array}$ & 50-120 items/day & $\begin{array}{l}\text { Fibre, frag- } \\
\text { ment, film, } \\
\text { sphere }\end{array}$ & Narmadha et al. (2020) \\
\hline East Indian Ocean & $\begin{array}{l}\text { Collection using a total suspended atmospheric par- } \\
\text { ticulate sampler }\end{array}$ & 0.4 item $/ 100 \mathrm{~m}^{3}$ & Fibre, fragment & Wang et al. (2020b) \\
\hline
\end{tabular}

in the databases. A summary of these studies is presented in Table 4. These studies have reported synthetic textiles to be the major source of MP fibres in the sampling locations while the presence of fragments, films and spheres has been linked with releases from fragmentation and disintegration of macroplastic debris. The transport of MPs due to the aeolian processes can play an important role in the contamination of terrestrial and aquatic environments. Understanding the importance of a healthy atmosphere in our lives, it becomes very important to do regressive research about MP prevalence, transport and fate in this
The dust samples in these studies were collected from outdoor (Patchaiyappan et al. 2020b) and indoor (Zhang et al. 2020) systems, and significant abundance of MPs was found, indicating the ubiquitous reach of these particles. According to the study conducted by Zhang et al. (2020), the estimated ingestion of MPs originating from the dust samples in different age groups (adults, teenagers, toddlers and infants) is $770-10,000 \mathrm{ng} / \mathrm{kg}$ bw/day (PET-based MPs) and 0.88-11.00 ng/kg bw/day (PCbased MPs). Furthermore, it has also been indicated that human exposure to MP particles via this route is much

Table 5 Presence of microplastics in dust samples

\begin{tabular}{|c|c|c|c|c|c|}
\hline Location & Location specification & Sampling technique & Concentration of MPs & Type of MPs & Reference \\
\hline Tamil Nadu (Chennai) & Outdoor street dust & $\begin{array}{l}\text { Collection by the quadrat } \\
\text { method using paint } \\
\text { brush, sterile paper } \& \\
\text { metal pan }\end{array}$ & 2279.4 items $/ \mathrm{kg}$ & Fragment, fibre & $\begin{array}{l}\text { Patchaiyappan et al. } \\
\text { (2020b) }\end{array}$ \\
\hline Bihar (Patna) & Indoor house dust & $\begin{array}{l}\text { Collection using vacuum } \\
\text { cleaner or direct sweep- } \\
\text { ing using nylon brush }\end{array}$ & $\begin{array}{l}12 \mu \mathrm{g} / \mathrm{g} \text { (free tereph- } \\
\text { thalic acid-based } \\
\text { MPs) } \\
2000 \mu \mathrm{g} / \mathrm{g} \text { (PET-based } \\
\mathrm{MPs} \text { ) } \\
0.71 \mu \mathrm{g} / \mathrm{g} \text { (free bisphe- } \\
\text { nol A-based MPs) } \\
20 \mu \mathrm{g} / \mathrm{g} \text { (polycarbon- } \\
\text { ate-based MPs) }\end{array}$ & Fibre & Zhang et al. (2020) \\
\hline
\end{tabular}

domain. The number of studies conducted in India is very limited to justify the problem of atmospheric MP and thus require scientist's and researcher's interventions.

\section{Microplastics in terrestrial systems}

With increased consumption of plastic items in our daily lives, their ageing and subsequent fragmentation leads to leaching of MPs in our terrestrial systems. The sources of these MPs can include mismanaged plastic waste, tyre wear and tear, fragmentation of construction and building materials, or aeolian transport of MPs from widespread sources (Patchaiyappan et al. 2020b). A summary of MPs detected in Indian terrestrial systems is shown in Table 5. more extensive in comparison to the consumable items. For instance, mussel consumption can cause an annual plastic consumption of 123 particles per capita and sea salt consumption can lead to ingestion of $0-36,135 \mathrm{MP}$ particles per capita, but exposure to dust in homes can lead to a huge exposure of $13,731-68,415$ particles per capita as suggested in some recent studies (Zhang et al. 2020; Peixoto et al. 2019; Catarino et al. 2018). Apart from this, in another study by Maity et al. (2020), the impacts of MP exposure were evaluated in a common terrestrial plant, i.e. Allium cepa (onion). This study has revealed cytogenotoxic impacts in A. cepa due to polystyrene MPs, indicating that the presence of MPs in our terrestrial environments has the potential to harm plant species as well as aquatic species, as discussed earlier. 
Table 6 Presence of microplastics in human consumables

\begin{tabular}{|c|c|c|c|c|c|c|}
\hline Location & Consumable item & $\begin{array}{l}\text { Concentration of } \\
\text { MPs }\end{array}$ & MP size $(\mu \mathrm{m})$ & Type of MPs & $\begin{array}{l}\text { Estimated risk of } \\
\text { exposure }\end{array}$ & Reference \\
\hline Kerala & Seafood (shellfish) & $\begin{array}{l}0.07 \text { item/indi- } \\
\text { vidual }\end{array}$ & 100 to 300 & $\begin{array}{l}\text { Fragment, sheet, } \\
\text { fibre }\end{array}$ & 13 items/year & Daniel et al. (2021) \\
\hline Pondicherry & Seafood (bivalve) & $\begin{array}{l}0-10.8 \text { items/indi- } \\
\text { vidual }\end{array}$ & $\begin{array}{l}\text { Less than } 100 \text { to } \\
1500\end{array}$ & Fragment & $\begin{array}{l}3917.79 \text { items/ } \\
\text { year }\end{array}$ & $\begin{array}{l}\text { Dowarah et al. } \\
(2020)\end{array}$ \\
\hline Kerala & Seafood (shrimps) & $\begin{array}{l}0.39 \text { item/indi- } \\
\text { vidual }\end{array}$ & 157 to 2785 & $\begin{array}{l}\text { Fibre, fragment, } \\
\text { sheet }\end{array}$ & - & Daniel et al. (2020) \\
\hline Tamil Nadu & $\begin{array}{l}\text { Sea \& bore-well } \\
\text { salt }\end{array}$ & $\begin{array}{l}\text { 35-72 items } / \mathrm{kg} \\
\text { (sea salt) } \\
2-29 \text { items } / \mathrm{kg} \\
\text { (bore-well salt) }\end{array}$ & 55 to 2000 & Fibre, fragment & $\begin{array}{l}216 \text { items/year } \\
\text { (sea salt) } \\
48 \text { items/year } \\
\text { (bore-well salt) }\end{array}$ & $\begin{array}{l}\text { Sathish et al. } \\
\text { (2020a) }\end{array}$ \\
\hline Tamil Nadu & Commercial salt & - & Less than 2000 & $\begin{array}{l}\text { Fragment, fibre, } \\
\text { sheet }\end{array}$ & - & $\begin{array}{l}\text { Selvam et al. } \\
\text { (2020b) }\end{array}$ \\
\hline $\begin{array}{l}\text { Supermarkets of } \\
\text { India }\end{array}$ & Commercial salt & $<700$ items $/ \mathrm{kg}$ & 3.8 to 5200 & $\begin{array}{l}\text { Fragment, fibre, } \\
\text { pellet }\end{array}$ & 1000 items/year & $\begin{array}{l}\text { Sivagami et al. } \\
(2020)\end{array}$ \\
\hline Tamil Nadu & Bottled water & $2-6$ items $/ \mathrm{L}$ & - & Fibre, fragment & - & $\begin{array}{l}\text { Ganesan et al. } \\
\text { (2019) }\end{array}$ \\
\hline $\begin{array}{l}\text { Kerala, Maharash- } \\
\text { tra \& Gujarat }\end{array}$ & $\begin{array}{l}\text { Commercial sea } \\
\text { salt }\end{array}$ & $56-103$ items/L & 0 to 5000 & Fibre, fragment & $117 \mu \mathrm{g} /$ year & $\begin{array}{l}\text { Seth \& Shriwastav } \\
\quad(2018)\end{array}$ \\
\hline $\begin{array}{l}\text { Supermarkets of } \\
\text { India }\end{array}$ & $\begin{array}{l}\text { Sea, rock \& lake } \\
\text { salt }\end{array}$ & 506 items $/ \mathrm{kg}$ & 100 to 5000 & $\begin{array}{l}\text { Fragment, fibre, } \\
\text { sheet }\end{array}$ & 2000 items/year & Kim et al. (2018) \\
\hline $\begin{array}{l}\text { Maharashtra, } \\
\text { Tamil Nadu \& } \\
\text { New Delhi }\end{array}$ & Bottled water & $\begin{array}{c}3.72-826.00 \\
\text { items } / \mathrm{L}\end{array}$ & $\begin{array}{l}6.5 \text { to greater than } \\
100\end{array}$ & $\begin{array}{l}\text { Fragment, fibre, } \\
\text { film, foam, pellet }\end{array}$ & - & Mason et al. (2018) \\
\hline New Delhi & Tap water & 4.34 items/L & 100 to 5000 & Fibre, fragment & $\begin{array}{l}\text { 3000-4000 items/ } \\
\text { year }\end{array}$ & Kosuth et al. (2017) \\
\hline
\end{tabular}

Presently, MPs are invading virtually every part of our environment but the extent of research conducted in India to evaluate the situation in terrestrial environments is very limited. It is important to scale up the research investigations in this area so that the current scenario can be better understood and necessary actions to manage this problem could be adopted at the earliest possible.

\section{Microplastics in human consumables}

Contamination of hydrosphere, atmosphere and lithosphere with MPs is now a well-established fact, but the extent of research interventions in these segments with reference to India is still a long way to go. The organisms inhabiting these systems are capable of consuming MPs, and their further interaction with humans imposes a significant risk of MP exposure to humans through ingestion or inhalation. The presence of MPs has recently been reported in various human consumables, viz. seafood, salt, drinking water and tap water in India, and this has attracted researcher's attention towards MP pollution. However, the types of samples collected for MP analysis varied from study to study like, for salt sample, direct collection from the salt pans was done in one study (Selvam et al. 2020b) while majority of other researchers preferred purchasing commercial salt samples from the market or salt manufacturing unit (Sathish et al. 2020a; Sivagami et al. 2020; Seth and Shrivastav 2020). Sea food sampling involved a collection of organisms directly from their natural habitats (Daniel et al. 2021, 2020; Dowarah et al. 2020). On the other hand, for drinking water analysis, packaged bottles were procured from the markets.

Due to the extensive usage of plastics in food packaging industry, the expanse of MPs is gradually dominating in human consumable items. The contamination of sources from where these consumable items are being extracted is also emerging as a cause of concern as it may affect the MP abundance in these items. For instance, in a recent study by Nithin et al. (2021), it has been suggested that manufacturing of consumable items like table salts from groundwater instead of seawater could lead to lesser MP contamination. In the present review, 11 studies have been found discussing the contamination and risk of exposure to humans by consumption of the items contaminated with MPs (Table 6). The risk of exposure was calculated by using the average dietary intake of that particular item and the amount of MPs present in the item. In a study by Sivagami et al. (2020), the harming potential of the MP particles to human embryonic kidney cells have been analysed and extreme conditions like cell 
Fig. 3 Gap areas in the microplastic research in Indian environments that need immediate attention

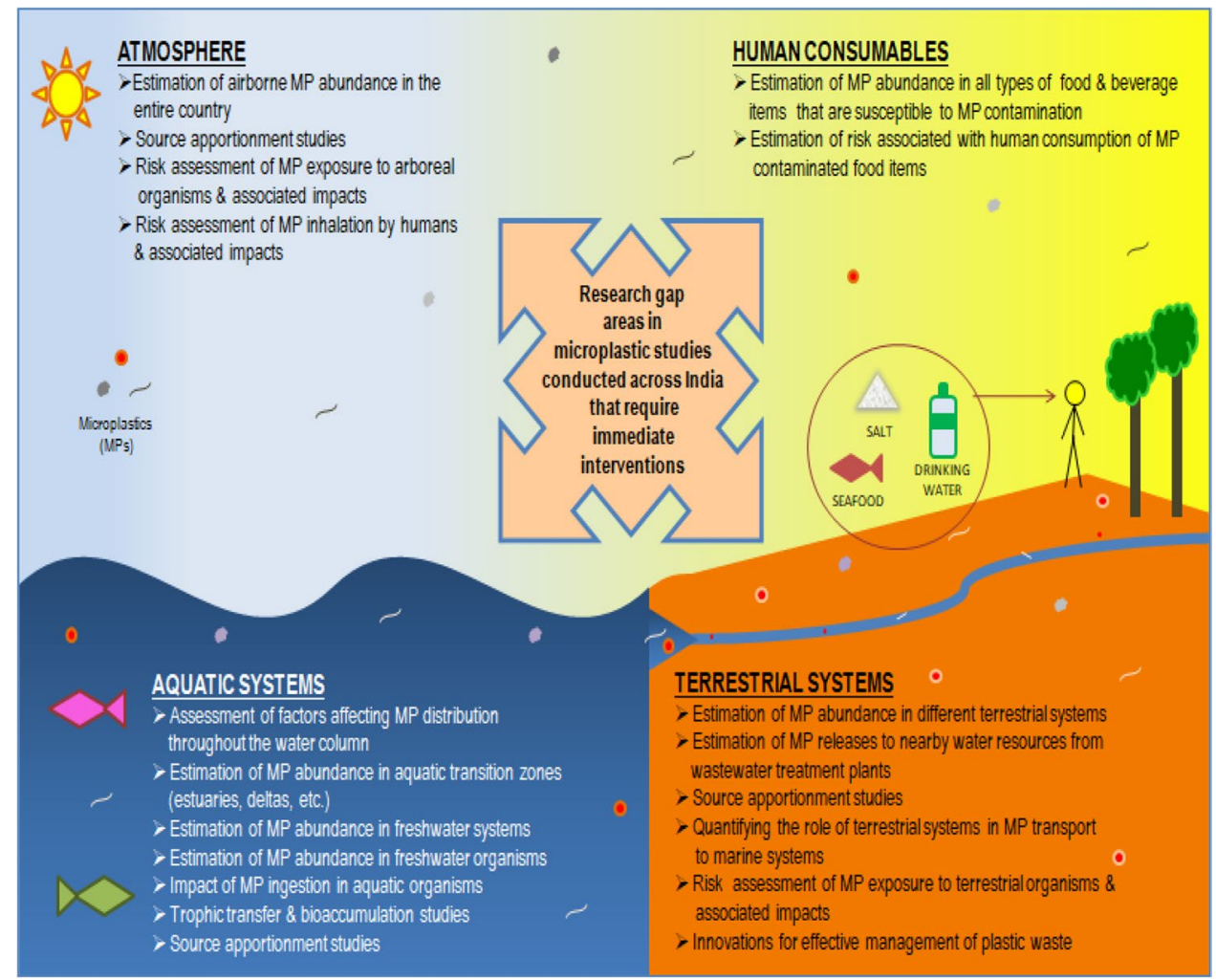

death of the exposed cells have been observed. This particular behaviour of cell detachment and apoptosis was observed after exposure of $24 \mathrm{~h}$. In another study by Sharma et al. (2020), the toxic effects of MP behaviour were evaluated in terms of cancer risk to human beings. The researchers have reported that the potential of MPs to adsorb a variety of pollutants can aid in aggravated health issues, if such MPs are ingested. For this particular study, when MPs were interacted with carcinogenic polycyclic aromatic hydrocarbons (PAHs), maximum adsorption of PAHs was achieved within 45 min of interaction and the cancer risk estimated was found to be significantly higher for PAH-adsorbed MPs. The number of studies discussing the impact of MP ingestion or inhalation in humans in India is very limited; therefore, in order to better understand the health complications associated with these synthetic polymers, it becomes very important to scale up the MP research in this domain.

\section{Conclusions and recommendations}

India being one of the major producers of plastic waste is gradually pacing up its research in microplastics. At present, the role of India in global MP pollution is not well understood. This study is an effort to identify the gaps and knowledge about MP pollution in different compartments of Indian environment. The database is found to have 64 studies, which is a very small number in comparison to the widespread reach of MP particles. A major portion of MP studies in this dataset has focussed on the marine environments, majorly the south-east coast with the highest number of studies done in the state of Tamil Nadu. Also, sediment portion has been more researched upon for MP contamination within the marine systems. In case of freshwater systems, the river section comprises the highest number of studies in comparison to the lakes and groundwater counterpart. However, the complete understanding of sources, pathways and fate of MPs in these aquatic systems needs to be addressed by the research community. On the other hand, atmosphere and terrestrial systems comprised merely two studies each, which is an insufficient number to understand the extent of MP pollution in these domains for the entire country.

Contamination of different environmental compartments with MPs has widened their expanse to human consumable items as their origin is linked to these matrices. Salt, drinking water, tap water and seafood are the only items that have been looked upon for MP contamination in India while worldwide MPs are being detected in a wide range of food and beverage items. The toxicity associated with these MPs has not been extensively focussed, and at present, the situation of MP prevalence in Indian food and beverage items is not very clear. The exploration of mechanisms involved in MP-associated toxicity to humans as well as other organisms 
is a very important aspect to be looked upon, considering the role of plastic items in our day-to-day lives. In addition to this, it is also very important to explore the capability of MPs to interact with other pollutants present in the Indian environments and the enhanced health impacts they might impose to the interacting biota after ingestion or inhalation.

With the increasing demand and production of plastics, MP contamination will continue to rise and may therefore cause serious damage to our environment. It is very important in the present times to scale up the research investigations at both the laboratory and field scales, with equal focus on each and every component of different environmental matrices comprising marine systems, freshwater systems, terrestrial systems, atmosphere, human consumables and associated toxicities. Furthermore, innovations should also be directed to develop suitable techniques for the removal of these MPs from these matrices. The present review has focussed on the important aspects of MP contamination in different segments of Indian environments, and each section has been discussed with the significant knowledge inputs and lag areas. Future scope and recommendations have also been suggested to cover the gaps in knowledge which will provide directions for future studies and improve the scope of MP research in India (Fig. 3).

Author contribution All the authors' have contributed in the conceptualization and designing of this article. Literature search and data analysis were performed by Ms. Mansi Vaid and Ms. Komal Mehra. The first draft of the manuscript was prepared by Ms. Mansi Vaid and Ms. Komal Mehra. Critical analysis and revision of the work were done by Dr. Anshu Gupta.

Funding This study was funded by Guru Gobind Singh Indraprastha University (GGSIPU) under Faculty Research Grant Scheme (FRGS) and University Grants Commission under Junior Research Fellowship (JRF).

Data availability The datasets analysed during the current study are cited in the reference list with their respective digital object identifier (DOI) wherever possible.

\section{Declarations}

Ethics approval and consent to participate Not applicable.

Consent for publication Not applicable.

Competing interests The authors declare no competing interests.

\section{References}

Ajith N, Arumugam S, Parthasarathy S, Manupoori S, Janakiraman S (2020) Global distribution of microplastics and its impact on marine environment-a review. Environ Sci Pollut Res 27:25970-25986. https://doi.org/10.1007/s11356-020-09015-5
Allen S, Allen D, Phoenix VR, Roux GL, Jiménez PD, Simonneau A, Binet S, Galop D (2019) Atmospheric transport and deposition of microplastics in a remote mountain catchment. Nat Geosci 12:339-344. https://doi.org/10.1038/s41561-019-0335-5

Amrutha K, Warrier AK (2020) The first report on the source-to-sink characterization of microplastic pollution from a riverine environment in tropical India. Sci Total Environ 739:140377. https:// doi.org/10.1016/j.scitotenv.2020.140377

Ashwini SK, Varghese GK (2019) Environmental forensic analysis of the microplastic pollution at "Nattika" Beach, Kerala Coast, India. Environ Forensics 21:21-36. https://doi.org/10.1080/ 15275922.2019.1693442

Balasubramaniam M, Phillott AD (2016). Preliminary observations of microplastics from beaches of Indian Ocean. In: Indian Ocean Turtle Newsletter No. 23, pp 13-16. http://seaturtle.org/libra ry/BalasubramaniamM_2016_IndOceanTurtleNewsletter.pdf. Accessed 15 May 2020

Barboza LGA, Gimenez BCG (2015) Microplastics in the marine environment: current trends and future perspectives. Mar Pollut Bull 97:5-12. https://doi.org/10.1016/j.marpolbul.2015.06.008

Barletta M, Lima ARA, Costa MF (2019) Distribution, sources and consequences of nutrients, persistent organic pollutants, metals and microplastics in South American estuaries. Sci Total Environ 651:1199-1218. https://doi.org/10.1016/j.scitotenv.2018.09.276

Barnes DKA, Galgani F, Thompson RC, Barlaz M (2009) Accumulation and fragmentation of plastic debris in global environments. Philos Trans R Soc Lond B Biol Sci 364:1985-1998. https://doi. org/10.1098/rstb.2008.0205

Bengtsson L, Herschy L (2012). Encyclopedia of lakes and reservoirs. In: Bengtsson L, Herschy RW, Fairbridge RW (Eds). Springer, Netherlands. https://doi.org/10.1007/978-1-4020-4410-6

Bhattacharya A, Khare SK (2019) Microplastic pollution: an overview of current scenario, challenges, and research gaps. Adv Biotech \& Micro 12(3):555836. https://doi.org/10.19080/AIBM.2019. 12.555836

Bhuyan MS, Venkatramanan S, Selvam S, Szabo S, Hossain MM, Rashed-Un-Nabi M, Paramasivam CR, Jonathan MP, Islam MS (2021) Plastics in marine ecosystem: a review of their sources and pollution conduits. Reg Stud Mar Sci 41:101539. https://doi. org/10.1016/j.rsma.2020.101539

Bi M, He Q, Chen Y (2020) What roles are terrestrial plants playing in global microplastic cycling? Environ Sci Technol 54:5325-5327. https://doi.org/10.1021/acs.est.0c01009

Brennecke D, Duarte B, Paiva F, Caçador I, Canning-Clode J (2016) Microplastics as vector for heavy metal contamination from the marine environment. Estuar Coast Shelf Sci 178:189-195. https://doi.org/10.1016/j.ecss.2015.12.003

Browne MA, Galloway TS, Thompson RC (2010) Spatial patterns of plastic debris along estuarine shorelines. Environ Sci Technol 44:3404-3409. https://doi.org/10.1021/es903784e

Browne MA, Niven SJ, Galloway TS, Rowland SJ, Thompson RC (2013) Microplastic moves pollutants and additives to worms, reducing functions linked to health and biodiversity. Curr Biol 23:2388-2392. https://doi.org/10.1016/j.cub.2013.10.012

Carlos de Sá L, Luís LG, Guilhermino L (2015) Effects of microplastics on juveniles of the common goby (Pomatoschistus microps): confusion with prey, reduction of the predatory performance and efficiency, and possible influence of developmental conditions. Environ Pollut 196:359-362. https://doi.org/10.1016/j.envpol. 2014.10.026

Catarino AI, Macchia V, Sanderson WG, Thompson RC, Henry TB (2018) Low levels of microplastics (MP) in wild mussels indicate that MP ingestion by humans is minimal compared to exposure via household fibres fallout during a meal. Environ Pollut 237:675-684. https://doi.org/10.1016/j.envpol.2018.02.069 
Cauwenberghe LV, Devriese L, Galgani F, Robbens J, Janssen CR (2015) Microplastics in sediments: a review of techniques, occurrence and effects. Mar Environ Res 111:5-17. https://doi.org/10. 1016/j.marenvres.2015.06.007

Central Water Commission (2019). Reassessment of water availability in India using space inputs. http://old.cwc.gov.in/main/downl oads/ReassessmentMainReport.pdf. Accessed 15 October 2020

Crawford CB, Quinn B (2017) Plastic production, waste and legislation. In: Crawford CB, Quinn B (Eds.) Microplastic pollutants. Elsevier Science, Amsterdam, pp 39-56. https://doi.org/10.1016/ B978-0-12-809406-8.00003-7

CSE (2019). The problem of plastics. https://cdn.cseindia.org/attac hments/0.57139300_1570431848_Factsheet1.pdf. Accessed 30 January 2021

Daniel DB, Ashraf PM, Thomas SN (2020) Abundance, characteristics and seasonal variation of microplastics in Indian white shrimps (Fenneropenaeus indicus) from coastal waters off Cochin, Kerala. India Sci Total Environ 737:139839. https://doi.org/10. 1016/j.scitotenv.2020.139839

Daniel DB, Ashraf PM, Thomas SN, Thomson KT (2021) Microplastics in the edible tissues of shellfishes sold for human consumption. Chemosphere 264:128554. https://doi.org/10.1016/j.chemo sphere.2020.128554

de Sousa FDB (2021) Plastic and its consequences during the COVID19 pandemic. Environ Sci Pollut Res 28:46067-46078. https:// doi.org/10.1007/s11356-021-15425-w

de Souza Machado AA, Kloas W, Zarfl C, Hempel S, Rillig MC (2018) Microplastics as an emerging threat to terrestrial ecosystems. Glob Chang Biol 24:1405-1416. https://doi.org/10.1111/gcb. 14020

Derraik JGB (2002) The pollution of the marine environment by plastic debris: a review. Mar Pollut Bull 44:842-852. https://doi.org/10. 1016/S0025-326X(02)00220-5

Devi SS, Sreedevi AV, Kumar AB (2020) First report of microplastic ingestion by the alien fish pirapitinga (Piaractus brachypomus) in the Ramsar site Vembanad Lake. South India Mar Pollut Bull 160:111637. https://doi.org/10.1016/j.marpolbul.2020.111637

Dowarah K, Devipriya SP (2019) Microplastic prevalence in the beaches of Puducherry, India and its correlation with fishing and tourism/recreational activities. Mar Pollut Bull 148:123-133. https://doi.org/10.1016/j.marpolbul.2019.07.066

Dowarah K, Patchaiyappan A, Thirunavukkarasu C, Jayakumar S, Devipriya SP (2020) Quantification of microplastics using Nile red in two bivalve species Perna viridis and Meretrix meretrix from three estuaries in Pondicherry, India and microplastic uptake by local communities through bivalve diet. Mar Pollut Bull 153:110982. https://doi.org/10.1016/j.marpolbul.2020. 110982

Dris R, Gasperi J, Saad M, Mirande C, Tassin B (2016) Synthetic fibers in atmospheric fallout: a source of microplastics in the environment? Mar Pollut Bull 104:290-293. https://doi.org/10.1016/j. marpolbul.2016.01.006

FICCI (2014). Potential of plastics industry in northern India with special focus on plasticulture and food processing. A report on plastics industry. http://ficci.in/spdocument/20396/KnowledgePaper-ps.pdf. Accessed 29 December 2020

Fok L, Cheung PK, Tang G, Li WC (2017) Size distribution of stranded small plastic debris on the coast of Guangdong, South China. Environ Pollut 220:407-412. https://doi.org/10.1016/j.envpol. 2016.09.079

Ganesan M, Nallathambi G, Srinivasalu S (2019). Fate and transport of microplastics from water sources. Curr Sci 117:1874-1879. https://wwwops.currentscience.ac.in/Volumes/117/11/1879.pdf. Accessed 17 May 2020

Gasperi J, Wright SL, Dris R, Collard F, Mandin C, Guerrouache M, Langlois V, Kelly FJ, Tassin B (2018) Microplastics in air: are we breathing it in? Curr Opin Environ Sci Health 1:1-5. https:// doi.org/10.1016/j.coesh.2017.10.002

Gayathri S, Krishnan KA, Krishnakumar A, Maya TMV, Dev VV, Antony S, Arun V (2021) Monitoring of heavy metal contamination in Netravati river basin: overview of pollution indices and risk assessment. Sustain Water Resour Manag 7. https://doi.org/ 10.1007/s40899-021-00502-2

GESAMP (2015). Sources, fate and effects of microplastics in the marine environment: a global assessment. www.gesamp.org/ site/assets/files/1275/sources-fate-and-effects-of-microplasticsin-the-marine-environment-part-2-of-a-global-assessment-en. pdf. Accessed 31 March 2021

Gopinath K, Seshachalam S, Neelavannan K, Anburaj V, Rachel M, Ravi S, Bharath M, Achyuthan H (2020) Quantification of microplastic in Red Hills Lake of Chennai City, Tamil Nadu, India. Environ Sci Pollut Res 27:33297-33306. https://doi.org/10.1007/ s11356-020-09622-2

Goswami P, Vinithkumar NV, Dharani G (2020) First evidence of microplastics bioaccumulation by marine organisms in the Port Blair Bay. Andaman Islands Mar Pollut Bull 155:111163. https:// doi.org/10.1016/j.marpolbul.2020.111163

Gurumoorthi K, Venkatachalapathy R (2016) Spatial and seasonal trends of heavy metals and ecological risk assessment along Kanyakumari coastal sediments, Southern India. Pollution 2:269-287. https://doi.org/10.7508/pj.2016.03.003

He B, Wijesiri B, Ayoko GA, Egodawatta P, Rintoul L, Goonetilleke A (2020) Influential factors on microplastics occurrence in river sediments. Sci Total Environ 738:139901. https://doi.org/10. 1016/j.scitotenv.2020.139901

Ingole SA, Kadam AN (2003). Pollution of some recreation beaches of Mumbai, Maharashtra. J Indian Assoc Environ Manage 30:172175. https://citeseerx.ist.psu.edu/viewdoc/download?doi=10.1.1. $504.9601 \&$ rep $=$ rep $1 \&$ type $=$ pdf. Accessed 15 May 2020

IQAir (2020). World air quality report. https://www.iqair.com/worldair-quality-report. Accessed 31 March 2021

Jabeen K, Li B, Chen Q, Su L, Wu C, Hollert H, Shi H (2018) Effects of virgin microplastics on goldfish (Carassius auratus). Chemosphere 213:323-332. https://doi.org/10.1016/j.chemosphere. 2018.09.031

James K, Vasant K, Padua S, Gopinath V, KS A, R J, Babu A, John S, (2020) An assessment of microplastics in the ecosystem and selected commercially important fishes off Kochi, south eastern Arabian Sea. India Mar Pollut Bull 154:111027. https://doi.org/ 10.1016/j.marpolbul.2020.111027

Jamieson AJ, Brooks LSR, Reid WDK, Piertney SB, Narayanaswamy BE, Linley TD (2019) Microplastics and synthetic particles ingested by deep-sea amphipods in six of the deepest marine ecosystems on Earth. R Soc Open Sci 6:180667-180667. https:// doi.org/10.1098/rsos.180667

Jayasiri HB, Purushothaman CS, Vennila A (2013a) Plastic litter accumulation on high-water strandline of urban beaches in Mumbai, India. Environ Monit Assess 185:7709-7719. https://doi.org/10. 1007/s10661-013-3129-z

Jayasiri HB, Purushothaman CS, Vennila A (2013b) Quantitative analysis of plastic debris on recreational beaches in Mumbai, India. Mar Pollut Bull 77:107-112. https://doi.org/10.1016/j. marpolbul.2013.10.024

Jayasiri HB, Vennila A, Purushothaman CS (2014) Spatial and temporal variability of metals in inter-tidal beach sediment of Mumbai, India. Environ Monit Assess 186:1101-1111. https://doi.org/10. 1007/s10661-013-3441-7

Jeyasanta KI, Patterson J, Grimsditch G, Edward JKP (2020a) Occurrence and characteristics of microplastics in the coral reef, sea grass and near shore habitats of Rameswaram Island. India Mar Pollut Bull 160:111674. https://doi.org/10.1016/j.marpolbul. 2020.111674 
Jeyasanta KI, Sathish N, Patterson J, Edward JKP (2020b) Macro-, meso- and microplastic debris in the beaches of Tuticorin district, southeast coast of India. Mar Pollut Bull 154:111055. https://doi. org/10.1016/j.marpolbul.2020.111055

Joseph P, Nandan SB, Adarsh KJ, Anu PR, Varghese R, Sreelekshmi S, Preethy CM, Jayachandran PR, Joseph KJ (2019) Heavy metal contamination in representative surface sediments of mangrove habitats of Cochin. Southern India Environ Earth Sci 78:490. https://doi.org/10.1007/s12665-019-8499-2

Karthik R, Robin RS, Purvaja R, Ganguly D, Anandavelu I, Raghuraman R, Hariharan G, Ramakrishna A, Ramesh R (2018) Microplastics along the beaches of southeast coast of India. Sci Total Environ 645:1388-1399. https://doi.org/10.1016/j.scitotenv. 2018.07.242

Karuppasamy PK, Ravi A, Vasudevan L, Elangovan MP, Mary PD, Vincent SGT, Palanisami T (2020) Baseline survey of micro and mesoplastics in the gastro-intestinal tract of commercial fish from southeast coast of the Bay of Bengal. Mar Pollut Bull 153:110974. https://doi.org/10.1016/j.marpolbul.2020.110974

Kim J-L, Lee H-L, Kim S-K, Kim H-J (2018) Global pattern of microplastics (MPs) in commercial food grade salts: sea salt as an indicator of seawater MP pollution. Environ Sci Technol 52:12819-12828. https://doi.org/10.1021/acs.est.8b04180

Klein S, Worch E, Knepper TP (2015) Occurrence and spatial distribution of microplastics in river shore sediments of the RhineMain Area in Germany. Environ Sci Technol 49:6070-6076. https://doi.org/10.1021/acs.est.5b00492

Kosuth M, Wattenberg EV, Mason SA, Tyree C, Morrison D (2017). Synthetic polymer contamination in global drinking water. https://orbmedia.org/stories/Invisibles_final_report. Accessed 22 October 2020

Krishnakumar S, Anbalagan S, Kasilingam K, Smrithi P, Anbazhagi S, Srinivasalu S (2020a) Assessment of plastic debris in remote islands of the Andaman and Nicobar Archipelago. India Mar Pollut Bull 151:110841. https://doi.org/10.1016/j.marpolbul. 2019.110841

Krishnakumar S, Srinivasalu S, Saravanan P, Vidyasakar A, Magesh NS (2018) A preliminary study on coastal debris in Nallathanni Island, Gulf of Mannar Biosphere Reserve, southeast coast of India. Mar Pollut Bull 131:547-551. https://doi.org/10.1016/j. marpolbul.2018.04.026

Krishnakumar S, Vidyasakar A, Anbalagan S, Godson PS, Kasilingam K, Parthasarathy P, Pradhap D, Saravanan P, Hariharan S, Rajkumar A, Neelavannan K, Magesh NS (2020b) Bioavailable trace metals and their ecological risks in the tourist beaches of the southeast coast of India. Mar Pollut Bull 160:111562. https://doi.org/10.1016/j.marpolbul.2020.111562

Kumar VE, Ravikumar G, Jeyasanta KI (2018) Occurrence of microplastics in fishes from two landing sites in Tuticorin, south east coast of India. Mar Pollut Bull 135:889-894. https://doi.org/ 10.1016/j.marpolbul.2018.08.023

Kumar VS, Pathak KC, Pednekar P, Raju NSN, Gowthaman R (2006). Coastal processes along the Indian coastline. Curr Sci 91:530-536. http://drs.nio.org/drs/bitstream/handle/2264/350/ Curr_Sci_91_530.pdf; sequence=1. Accessed 15 May 2020

Law KL, Morét-Ferguson S, Maximenko NA, Proskurowski G, Peacock EE, Hafner J, Reddy CM (2010) Plastic accumulation in the North Atlantic subtropical gyre. Science 329:5996. https:// doi.org/10.1126/science.1192321

Law KL, Starr N, Siegler TR, Jambeck JR, Mallos NJ, Leonard GH (2020) The United States' contribution of plastic waste to land and ocean. Sci Adv 6:eabd0288. https://doi.org/10.1126/sciadv. abd0288

Lechner A, Keckeis H, Lumesberger-Loisl F, Zens B, Krusch R, Tritthart M, Glas M, Schludermann E (2014) The Danube so colourful: a potpourri of plastic litter outnumbers fish larvae in Europe's second largest river. Environ Pollut 188:177-181. https://doi.org/10.1016/j.envpol.2014.02.006

Lima ARA, Costa MF, Barletta M (2014) Distribution patterns of microplastics within the plankton of a tropical estuary. Environ Res 132:146-155. https://doi.org/10.1016/j.envres.2014. 03.031

Liu K, Wang X, Fang T, Xu P, Zhu L, Li D (2019) Source and potential risk assessment of suspended atmospheric microplastics in Shanghai. Sci Total Environ 675:462-471. https://doi.org/10. 1016/j.scitotenv.2019.04.110

Ma Y, Huang A, Cao S, Sun F, Wang L, Guo H, Ji R (2016) Effects of nanoplastics and microplastics on toxicity, bioaccumulation, and environmental fate of phenanthrene in fresh water. Environ Pollut 219:166-173. https://doi.org/10.1016/j.envpol.2016.10.061

Madhav NV, Gopinath KP, Krishnan A, Rajendran N, Krishnan A (2020) A critical review on various trophic transfer routes of microplastics in the context of the Indian coastal ecosystem. WEE 2:25-41. https://doi.org/10.1016/j.wsee.2020.08.001

Maharana D, Saha M, Dar JY, Rathore C, Sreepada RA, Xu X-R, Koongolla JB, Li H-X (2020) Assessment of plastics along the west coast of India: abundance, distribution, polymer type and toxicity. Chemosphere 246:125708. https://doi.org/10.1016/j. chemosphere.2019.125708

Maity S, Chatterjee A, Guchhait R, De S, Pramanick K (2020) Cytogenotoxic potential of a hazardous material, polystyrene microparticles on Allium cepa L. J Hazard Mater 385:121560. https:// doi.org/10.1016/j.jhazmat.2019.121560

Mani T, Hauk A, Walter U, Burkhardt-Holm P (2016) Microplastics profile along the Rhine River. Sci Rep 5:17988. https://doi.org/ $10.1038 /$ srep 17988

Manickavasagam S, Kumar S, Kumar K, Bhuvaneswari GR, Paul T, Shukla SP (2020) Quantitative assessment of influx and efflux of marine debris in a water channel of South Juhu creek, Mumbai. India Reg Stud Mar Sci 34:101095. https://doi.org/10.1016/j. rsma.2020.101095

Manikanda Bharath K, Srinivasalu S, Natesan U, Ayyamperumal R, Kalam N, Anbalagan S, Sujatha K, Alagarasan C (2020) Microplastics as an emerging threat to the freshwater ecosystems of Veeranam Lake in South India: a multidimensional approach. Chemosphere 264:128502. https://doi.org/10.1016/j.chemo sphere.2020.128502

Mason SA, Welch VG, Neratko J (2018) Synthetic polymer contamination in bottled water. Front Chem 6:407. https://doi.org/10.3389/ fchem.2018.00407

Mugilarasan M, Venkatachalapathy R, Sharmila N, Gurumoorthi K (2017). Occurrence of microplastic resin pellets from Chennai and Tinnakkara Island: towards the establishment of background level for plastic pollution. Indian J Geo-Mar Sci 46:1210-1212. http://nopr.niscair.res.in/handle/123456789/41992. Accessed 15 May 2020

Müller YK, Wernicke T, Pittroff M, Witzig CS, Storck FR, Klinger J, Zumbülte N (2020) Microplastic analysis-are we measuring the same? Results on the first global comparative study for microplastic analysis in a water sample. Anal Bioanal Chem 412:555-560. https://doi.org/10.1007/s00216-019-02311-1

Naidu SA (2019) Preliminary study and first evidence of presence of microplastics and colorants in green mussel, Perna viridis (Linnaeus, 1758), from southeast coast of India. Mar Pollut Bull 140:416-422. https://doi.org/10.1016/j.marpolbul.2019.01.024

Naidu SA, Rao VR, Ramu K (2018) Microplastics in the benthic invertebrates from the coastal waters of Kochi, Southeastern Arabian Sea. Environ Geochem Health 40:1377-1383. https://doi.org/10. 1007/s10653-017-0062-z 
Naik RK, Naik MM, D’Costa PM, Shaikh F (2019) Microplastics in ballast water as an emerging source and vector for harmful chemicals, antibiotics, metals, bacterial pathogens and HAB species: a potential risk to the marine environment and human health. Mar Pollut Bull 149:110525. https://doi.org/10.1016/j. marpolbul.2019.110525

Napper IE, Baroth A, Barrett AC, Bhola S, Chowdhury GW, Davies BFR, Duncan EM, Kumar S, Nelms SE, Niloy MNH, Nishat B, Maddalene T, Thompson RC, Koldewey H (2021) The abundance and characteristics of microplastics in surface water in the transboundary Ganges River. Environ Pollut 274:116348. https:// doi.org/10.1016/j.envpol.2020.116348

Narmadha VV, Jose J, Patil S, Farooqui MO, Srimuruganandam B, Saravanadevi S, Krishnamurthi K (2020) Assessment of microplastics in roadside suspended dust from urban and rural environment of Nagpur, India. Int J Environ Res 14:629-640. https://doi. org/10.1007/s41742-020-00283-0

Naushad SS, Lall AM, Charan AA (2014) Determination of heavy metals in water of Ganga and Yamuna River basin in Allahabad. Int J Curr Res 6:10131-10133. https://doi.org/10.15740/HAS/ AJES/9.2/106-108

Nigam R (1982). Plastic pellets on the Caranzalem Beach sands. India Mahasagar Bull Natl Inst Oceanogr 15:125-127. http://ijs.nio. org/index.php/msagar/article/download/2196/2172. Accessed 29 November 2020

Nithin A, Sundaramanickam A, Surya P, Sathish M, Soundharapandiyan B, Balachandar K (2021) Microplastic contamination in salt pans and commercial salts - a baseline study on the salt pans of Marakkanam and Parangipettai, Tamil Nadu. India Mar Pollut Bull 165:112101. https://doi.org/10.1016/j.marpolbul.2021. 112101

Nobi EP, Dilipan E, Thangaradjou T, Sivakumar K, Kannan L (2010) Geochemical and geo-statistical assessment of heavy metal concentration in the sediments of different coastal ecosystems of Andaman Islands, India. Estuar Coast Shelf Sci 87:253-264. https://doi.org/10.1016/j.ecss.2009.12.019

NPC 2020. Promotion of counter measures against marine plastic litter in South East Asia and India. Plastic leakage pathways. https:// www.npcindia.gov.in/NPC/Uploads/file\%20upload/Plastic\% 20Leakage\%20Pathways.pdf. Accessed 15 July 2020

Ogata Y, Takada H, Mizukawa K, Hirai H, Iwasa S, Endo S, Mato Y, Saha M, Okuda K, Nakashima A, Murakami M, Zurcher N, Booyatumanondo R, Zakaria MP, Dung LQ, Gordon M, Miguez C, Suzuki S, Moore C, Karapanagioti HK, Weerts S, McClurg T, Burres E, Smith W, Velkenburg MV, Lang JS, Lang RC, Laursen D, Danner B, Stewardson N, Thompson RC (2009) International Pellet Watch: global monitoring of persistent organic pollutants (POPs) in coastal waters. 1. Initial phase data on PCBs, DDTs, and HCHs. Mar Pollut Bull 58:1437-1446. https://doi.org/10. 1016/j.marpolbul.2009.06.014

Pal R, Dubey RK, Dubey SK, Singh AK (2017) Assessment of heavy metal pollution through index analysis for Yamuna water in Agra region, India. Int J Curr Microbiol Appl Sci 6:1491-1498. https:// doi.org/10.20546/ijcmas.2017.612.166

Pandey D, Singh A, Ramanathan A, Kumar M (2021) The combined exposure of microplastics and toxic contaminants in the floodplains of north India: a review. J Environ Manage 279:111557. https://doi.org/10.1016/j.jenvman.2020.111557

Patchaiyappan A, Ahmed SZ, Dowarah K, Jayakumar S, Devipriya SP (2020a) Occurrence, distribution and composition of microplastics in the sediments of South Andaman beaches. Mar Pollut Bull 156:111227. https://doi.org/10.1016/j.marpolbul.2020.111227

Patchaiyappan A, Dowarah K, Ahmed SZ, Prabakaran M, Jayakumar S, Thirunavukkarasu C, Devipriya SP (2020b) Prevalence and characteristics of microplastics present in the street dust collected from Chennai metropolitan city. India Chemosphere 1269:28757. https://doi.org/10.1016/j.chemosphere.2020.128757

Patel AK, Bhagat C, Taki K, Kumar M (2020) Microplastic vulnerability in the sediments of the Sabarmati River of India. In: Kumar M, Munoz-Arriola F, Furumai H, Chaminda T (eds) Resilience, response, and risk in water systems. Springer Transactions in Civil and Environmental Engineering. Springer, Singapore, pp 127-138. https://doi.org/10.1007/978-981-15-4668-6_7

Patterson J, Jeyasanta KI, Sathish N, Booth AM, Edward JKP (2019) Profiling microplastics in the Indian edible oyster, Magallana bilineata collected from the Tuticorin coast, Gulf of Mannar, Southeastern India. Sci Total Environ 691:727-735. https://doi. org/10.1016/j.scitotenv.2019.07.063

Patterson J, Jeyasanta KI, Sathish N, Edward JKP, Booth AM (2020) Microplastic and heavy metal distributions in an Indian coral reef ecosystem. Sci Total Environ 744:140706. https://doi.org/ 10.1016/j.scitotenv.2020.140706

Peeken I, Primpke S, Beyer B, Julia G, Christian K, Thomas K, Melanie B, Laura H, Gunnar G (2018) Microplastic and environmental data from Arctic sea ice. Pangaea. https://doi.org/10.1594/ PANGAEA.886593

Peixoto D, Pinheiro C, Amorim J, Oliva-Teles L, Guilhermino L, Vieira MN (2019) Microplastic pollution in commercial salt for human consumption: a review. Estuar Coast Shelf Sci 219:161-168. https://doi.org/10.1016/j.ecss.2019.02.018

Pradhap D, Srinivasalu S, Silva JD, Parthasarathy P, Krishnakumar S, Saravanan P (2017) Trace element accumulation and depositional environment surface sediments, Off Rameshwaram, Gulf of Mannar, India. Front Cur Trends Engg Tech 2:8-18

Prata JC (2018) Airborne microplastics: consequences to human health? Environ Pollut 234:115-126. https://doi.org/10.1016/j. envpol.2017.11.043

Ragusa A, Svelato A, Santacroce C, Catalano P, Notarstefano V, Carnevali O, Papa F, Rongioletti MCA, Baiocco F, Draghi S, D’Amore E, Rinaldo D, Matta M, Giorgini E (2021) Plasticenta: first evidence of microplastics in human placenta. Environ Int 146:106274. https://doi.org/10.1016/j.envint.2020.106274

Rajaram R, Ganeshkumar A, Vinothkumar S, Arun G (2020) Ecological risk assessment of toxic metals contamination in Tuticorin coast of Gulf of Mannar, Southern India. Chem Ecol 37:132148. https://doi.org/10.1080/02757540.2020.1819986

Ram B, Kumar M (2020). Correlation appraisal of antibiotic resistance with fecal, metal and microplastic contamination in a tropical Indian river, lakes and sewage. npj Clean Water 3:3. https://doi. org/10.1038/s41545-020-0050-1

Ravindran VS, Rajesh S (2013). Physico-chemical characteristics and distribution of heavy metals along the Punnakayal estuary, SE coast, India. Int J Curr Res 5:141-147. http://www.journalcra. com/sites/default/files/issue-pdf/2956.pdf. Accessed 5 December 2020

Rech S, Macaya-Caquilpán V, Pantoja JF, Rivadeneira MM, Madariaga DJ, Thiel M (2020) Rivers as a source of marine litter-a study from the SE Pacific. Mar Pollut Bul 82:66-75. https://doi.org/10. 1016/j.marpolbul.2014.03.019

Reddy MS, Basha S, Adimurthy S, Ramachandraiah G (2006) Description of the small plastics fragments in marine sediments along the Alang-Sosiya ship-breaking yard, India. Estuar Coast Shelf Sci 68:656-660. https://doi.org/10.1016/j.ecss.2006.03.018

Reddy MS, Basha S, Kumar VGS, Joshi HV, Ramachandraiah G (2004) Distribution, enrichment and accumulation of heavy metals in coastal sediments of Alang-Sosiya ship scrapping yard, India. Mar Pollut Bull 48:1055-1059. https://doi.org/10.1016/j.marpo lbul.2003.12.011

Rezania S, Park J, Md Din MF, Taib SM, Talaiekhozani A, Yadav KK, Kamyab H (2018) Microplastics pollution in different aquatic environments and biota: a review of recent studies. Mar Pollut 
Bull 133:191-208. https://doi.org/10.1016/j.marpolbul.2018.05. 022

Robin RS, Karthik R, Purvaja R, Ganguly D, Anandavelu I, Mugilarasan M, Ramesh R (2020) Holistic assessment of microplastics in various coastal environmental matrices, southwest coast of India. Sci Total Environ 703:134947. https://doi.org/10.1016/j. scitotenv.2019.134947

Sachithanandam V, Parthasarathy P, Elangovan SS, Kasilingam K, Dhivya P, Mageswaran T, Mohan PM (2020) A baseline study on trace metals concentration and its ecological risk assessment from the coast of South Andaman Island. India Reg Stud Mar Sci 36:101242. https://doi.org/10.1016/j.rsma.2020.101242

Sarkar DJ, Sarkar SD, Das BK, Manna RK, Behera BK, Samanta S (2019) Spatial distribution of meso and microplastics in the sediments of river Ganga at eastern India. Sci Total Environ 694:133712. https://doi.org/10.1016/j.scitotenv.2019.133712

Sarkar DJ, Sarkar SD, Manna RK, Samanta S, Das BK (2020). Microplastics pollution: an emerging threat to freshwater aquatic ecosystem of India. JIFSI 52:5-15. https://doi.org/10.47780/jifsi. 52.1.2020.106513

Sathish MN, Jeyasanta I, Patterson J (2020a) Microplastics in salt of Tuticorin, southeast coast of India. Arch Environ Contam Toxicol 79:111-121. https://doi.org/10.1007/s00244-020-00731-0

Sathish MN, Jeyasanta I, Patterson J (2020b) Occurrence of microplastics in epipelagic and mesopelagic fishes from Tuticorin, southeast coast of India. Sci Total Environ 720:137614. https:// doi.org/10.1016/j.scitotenv.2020.137614

Sathish MN, Jeyasanta KI, Patterson J (2020c) Monitoring of microplastics in the clam Donax cuneatus and its habitat in Tuticorin coast of Gulf of Mannar (GoM). India Environ Pollut 266:115219. https://doi.org/10.1016/j.envpol.2020.115219

Sathish N, Jeyasanta KI, Patterson J (2019) Abundance, characteristics and surface degradation features of microplastics in beach sediments of five coastal areas in Tamil Nadu, India. Mar Pollut Bull 142:112-118. https://doi.org/10.1016/j.marpo lbul.2019.03.037

Sedlak D (2017) Three lessons for the microplastics voyage. Environ Sci Technol 51:7747-7748. https://doi.org/10.1021/acs.est. $7 \mathrm{~b} 03340$

Selvam S, Jesuraja K, Venkatramamam S, Roy PD, Kumari VJ (2020a) Hazardous microplastic characteristics and its role as heavy metal in groundwater and surface water of coastal south India. J Hazard Mater 402:123786. https://doi.org/10.1016/j.jhazmat. 2020.123786

Selvam S, Manisha A, Venkatramanan S, Chung SY, Paramasivam CR, Singaraja C (2020b) Microplastic presence in commercial marine sea salts: a baseline study along Tuticorin Coastal salt pan stations, Gulf of Mannar. South India Mar Pollut Bull 150:110675. https://doi.org/10.1016/j.marpolbul.2019.110675

Seth CK, Shriwastav A (2018) Contamination of Indian sea salts with microplastics and a potential prevention strategy. Environ Sci Pollut Res 25:30122-30131. https://doi.org/10.1007/ s11356-018-3028-5

Sharma MD, Elanjickal AI, Mankar JS, Krupadam RJ (2020) Assessment of cancer risk of microplastics enriched with polycyclic aromatic hydrocarbons. J Hazard Mater 398:122994. https://doi. org/10.1016/j.jhazmat.2020.122994

Shyleshchandran MN, Mohan M, Ramasamy EV (2018) Risk assessment of heavy metals in Vembanad Lake sediments (south-west coast of India), based on acid-volatile sulfide (AVS)-simultaneously extracted metal (SEM) approach. Environ Sci Pollut Res 25:7333-7345. https://doi.org/10.1007/s11356-017-0997-8

Siddiqui E, Pandey J (2019) Assessment of heavy metal pollution in water and surface sediment and evaluation of ecological risks associated with sediment contamination in the Ganga River: a basin-scale study. Environ Sci Pollut Res 26:10926-10940. https://doi.org/10.1007/s11356-019-04495-6

Sivagami M, Selvambigai M, Devan U, Velangani AAJ, Karmegam N, Biruntha M, Arun A, Kim W, Govarthanan M, Kumar P (2020) Extraction of microplastics from commonly used sea salts in India and their toxicological evaluation. Chemosphere 263:128181. https://doi.org/10.1016/j.chemosphere.2020.128181

Solai S, Gandhi MS, Kasilingam K, Sriraman E (2013). Heavy metal accumulation in the surface sediments off Pondicherry, Bay of Bengal, south east coast of India. Int J Innov Res Sci Eng Technol 2:5741-5753. https://www.rroij.com/open-access/heavy-metalaccumulation-in-the-surfacesediments-off-pondicherry-bay-ofbengalsouth-east-coast-of-india.pdf. Accessed 15 May 2020

Sruthy S, Ramasamy EV (2017) Microplastic pollution in Vembanad Lake, Kerala, India: the first report of microplastics in lake and estuarine sediments in India. Environ Pollut 222:315-322. https://doi.org/10.1016/j.envpol.2016.12.038

Suman TY, Li W-G, Alif S, Faris VRP, Amarnath DJ, Ma JG, Pei D-S (2020) Characterization of petroleum-based plastics and their absorbed trace metals from the sediments of the Marina Beach in Chennai. India Environ Sci Eur 32:110. https://doi.org/10.1186/ s12302-020-00388-5

Sundar S, Chokkalingam L, Roy PD, Usha T (2020) Estimation of microplastics in sediments at the southernmost coast of India (Kanyakumari). Environ Sci Pollut Res 28:18495-18500. https:// doi.org/10.1007/s11356-020-10333-x

Suresh G, Sutharsan P, Ramasamy V, Venkatachalapthy R (2012) Assessment of spatial distribution and potential ecological risk of the heavy metals in relation to granulometric contents of Veeranam lake sediments, India. Ecotoxicol Environ Saf 84:117-124. https://doi.org/10.1016/j.ecoenv.2012.06.027

Thangaradjou T, Subhashini P, Raja S, Dilipan E, Nobi EP (2014) Evidences for heavy metal contamination in surface sediments of seagrass ecosystem of Lakshadweep archipelago, India. Environ Earth Sci 71:1135-1146. https://doi.org/10.1007/ s12665-013-2517-6

Tholkappian M, Ravisankar R, Chandrasekaran A, Jebakumar JPP, Kanagasabapathy KV, Prasad MVR, Satapathy KK (2018) Assessing heavy metal toxicity in sediments of Chennai Coast of Tamil Nadu using energy dispersive X-ray fluorescence spectroscopy (EDXRF) with statistical approach. Toxicol Rep 5:173-182. https://doi.org/10.1016/j.toxrep.2017.12.020

Thompson RC, Swan SH, Moore CJ, vom Saal FS (2009) Our plastic age. Philos Trans R Soc Lond B Biol Sci 364:1973-1976. https:// doi.org/10.1098/rstb.2009.0054

Tiwari M, Rathod TD, Ajmal PY, Bhangare RC, Sahu SK (2019) Distribution and characterization of microplastics in beach sand from three different Indian coastal environments. Mar Pollut Bull 140:262-273. https://doi.org/10.1016/j.marpolbul.2019.01.055

Veerasingam S, Mugilarasan M, Venkatachalapathy R, Vethamony P (2016a) Influence of 2015 flood on the distribution and occurrence of microplastic pellets along the Chennai coast, India. Mar Pollut Bull 109:196-204. https://doi.org/10.1016/j.marpo lbul.2016.05.082

Veerasingam S, Ranjani M, Venkatachalapathy R, Bagaev A, Mukhanov V, Litvinyuk D, Verzhevskaia L, Guganathan L, Vethamony P (2020) Microplastics in different environmental compartments in India: analytical methods, distribution, associated contaminants and research needs. TrAC 133:116071. https://doi.org/10. 1016/j.trac.2020.116071

Veerasingam S, Saha M, Suneel V, Vethamony P, Rodrigues AC, Bhattacharyya S, Naik BG (2016b) Characteristics, seasonal distribution and surface degradation features of microplastic pellets along the Goa coast, India. Chemosphere 159:496-505. https:// doi.org/10.1016/j.chemosphere.2016.06.056 
Vianello A, Jensen RL, Liu L, Vollertsen J (2019) Simulating human exposure to indoor airborne microplastics using a breathing thermal manikin. Sci Rep 9:8670. https://doi.org/10.1038/ s41598-019-45054-w

Vidyasakar A, Krishnakumar S, Kasilingam K, Neelavannan K, Bharathi VA, Godson PS, Prabha K, Magesh NS (2020) Characterization and distribution of microplastics and plastic debris along Silver Beach. Southern India Mar Pollut Bull 158:111421. https:// doi.org/10.1016/j.marpolbul.2020.111421

Vidyasakar A, Neelavannan K, Krishnakumar S, Prabaharan G, Priyanka TSA, Magesh NS, Godson PS, Srinivasalu S (2018) Macrodebris and microplastic distribution in the beaches of Rameswaram Coral Island, Gulf of Mannar, southeast coast of India: a first report. Mar Pollut Bull 137:610-616. https://doi. org/10.1016/j.marpolbul.2018.11.007

Wagner M, Scherer C, Alvarez-Muñoz D, Brennholt N, Bourrain X, Buchinger S, Fries E, Grosbois C, Klasmeier J, Marti T, Rodriguez-Mozaz S, Urbatzka R, Vethaak AD, Winther-Nielsen M, Reifferscheid G (2014) Microplastics in freshwater ecosystems: what we know and what we need to know. Environ Sci Eur 26:12. https://doi.org/10.1186/s12302-014-0012-7

Waller CL, Griffiths HJ, Waluda CM, Thorpe SE, Loaiza I, Moreno B, Pacherres CO, Hughes KH (2017) Microplastics in the Antarctic marine system: an emerging area of research. Sci Tot Environ 598:220-227. https://doi.org/10.1016/j.scitotenv.2017.03.283

Wang W, Ge J, Yu X (2020a) Bioavailability and toxicity of microplastics to fish species: a review. Ecotoxicol Environ Saf 189:109913. https://doi.org/10.1016/j.ecoenv.2019.109913
Wang X, Li C, Liu K, Zhu L, Song Z, Li D (2020b) Atmospheric microplastic over the South China Sea and East Indian Ocean: abundance, distribution and source. J Hazard Mater 389:121846. https://doi.org/10.1016/j.jhazmat.2019.121846

Waring RH, Harris RM, Mitchell SC (2018) Plastic contamination of the food chain: a threat to human health? Maturitas 115:64-68. https://doi.org/10.1016/j.maturitas.2018.06.010

World Economic Forum (2016). The new plastics economy: rethinking the future of plastics. http://www3.weforum.org/docs/WEF_ The_New_Plastics_Economy.pdf. Accessed 30 November 2020

Wright SL, Thompson RC, Galloway TS (2013) The physical impacts of microplastics on marine organisms: a review. Environ Pollut 178:483-492. https://doi.org/10.1016/j.envpol.2013.02.031

Zbyszewski M, Corcoran PL (2011) Distribution and degradation of fresh water plastic particles along the beaches of Lake Huron Canada. Water Air Soil Pollut 220:365-372. https://doi.org/10. 1007/s11270-011-0760-6

Zhang J, Wang L, Kannan K (2020) Microplastics in house dust from 12 countries and associated human exposure. Environ Int 134:105314. https://doi.org/10.1016/j.envint.2019.105314

Publisher's Note Springer Nature remains neutral with regard to jurisdictional claims in published maps and institutional affiliations. 